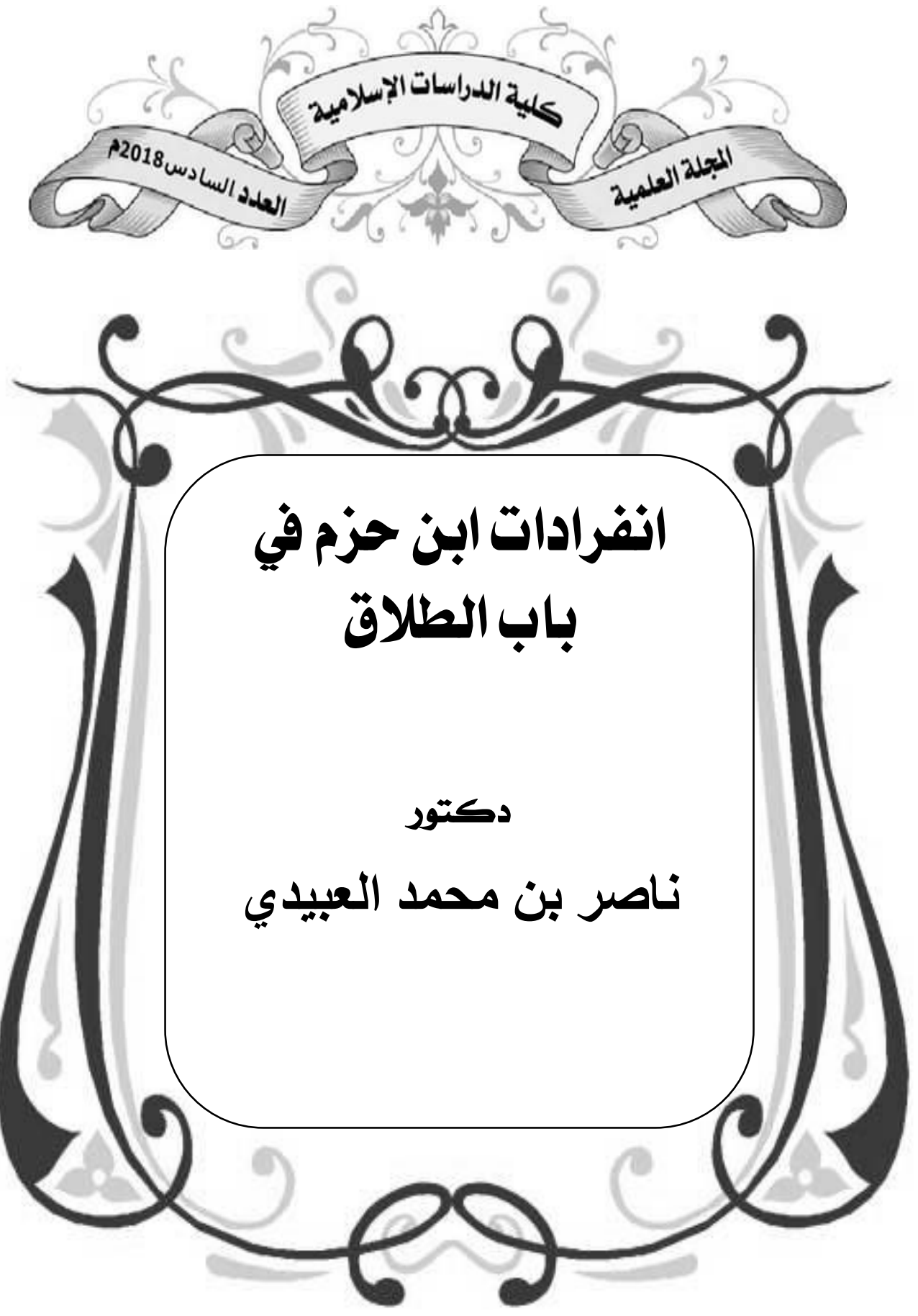


انفر ادات ابن حزم في باب الطلاق

'divorce 'chapter 'Ibn Hazm 'Keywords: uniqueness

virtual. 'Jurisprudence

Abstract:

I reviewed through this study the 'In this research

This 'uniqueness of Ibn Hazm in the divorce chapter study aimed to define Ibn Hazm as Imam of the virtual

And the definition of the virtual 'doctrine Imams And show the efforts 'doctrine and how it originated of Ibn Hazm in reviving the virtual doctrine and As well as clarifying the curriculum of Ibn 'renewing it It concludes with the mention 'Hazm fundamentalist of Ibn Hazm's uniqueness in the divorce chapter.

preface and two 'The study included an introduction each of them includes several demands and 'sections then the conclusion.

The introduction was on the importance of the topic 'objectives 'and the reasons for its choice then defined it in the 'methodology and research plan preface to the Ibn Hazm El-Zahery by presenting his then talked in the first topic about 'brief translation and the efforts of 'the origins of the virtual doctrine and it concluded ' Ibn Hazm in his revival and renewal Then in 'in the curriculum of Ibn Hazm Fundamentalist the second section I mentioned the uniqueness of Ibn

Which I outlined in six 'Hazm in the divorce chapter and showed and explained it with 'individualities Jurisprudence 'evidence through Ibn Hazm books especially comparative bbooks and other origins jurisprudence.

Finally the conclusion addressed the most important findings of the research and related to its divisions illustrated by the research plan.

$$
\text { الطلمات المفتاحية: انفر ادات، ابن حزم، باب، الظقاهري، }
$$

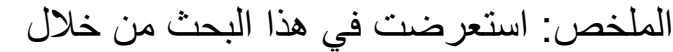

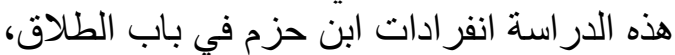

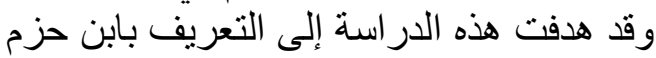

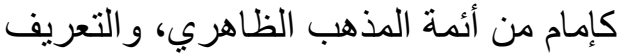

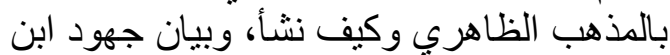
حزم في إحياء المذهب الظاهري وتجديده، وكذلك توضيح منهج ابن حزم الأصولي، وختمتها بذكر إندر

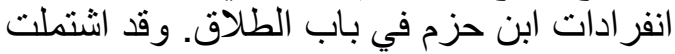
الدر اسة على مقدمة وتمهيد ومبحثين، كل مبحثي بـث

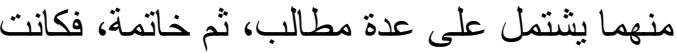

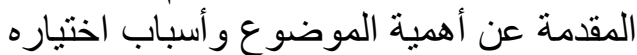

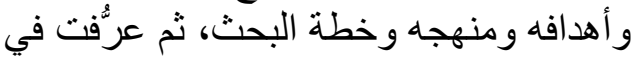
التمهيد بابن حزم الظاهري من خلافل عرضه وضه ترجمة موجزة لله، ثم تحدثت في المبحث المن الأول فرل عن نشأة المذهب الظاهري، وجهود ونه ابن حزم في في

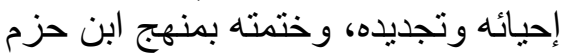
الأصولي، ثم في المبحث الثاني ذكرث انته انفر ادات

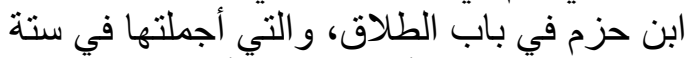
انفر ادات، وبينتها وأوضحتها فيالأدلة من خلاّل كتب ابن حزم وكتب الفقه و أصوله الأخرى الفى الأله

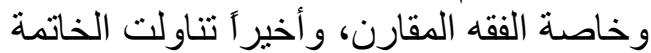

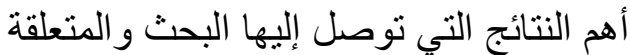
بتقسيماته الموضحة من خلال خطة البحث. 


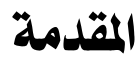

الحمد لله منزل الكتاب، المنعم الوهاب، والصـلاة والسـلام على خـاتم

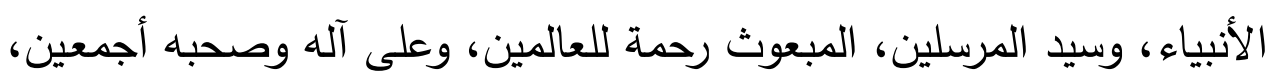

ومن تبعهم بإحسان إلى يوم الدين.

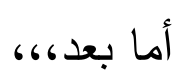

إن ساحة الفقه الإسلامي تذخر على مر السنين بالعلماء المجتهدين،

ومنهم أعلام بزغت شموسهم، وتأصلت مذاهبهم، حتى صلاروا أعلاماً من أعلام الحضارة الإسلامية، ومنهم الإمام الفقيه ابن حزم محيي المذهب الظهاهي الظهاهري في الأندلس، وهو المذهب الذي أنشأه وأسس له الإمام أبو داود الظاهري في بغداد الإد الناديه قبل مولد ابن حزم بما يقارب المائة وخمسين سنة. وإن كان ابن حزم من العلماء البارزين في الأندلس بوجه خاص، فهو من الإن

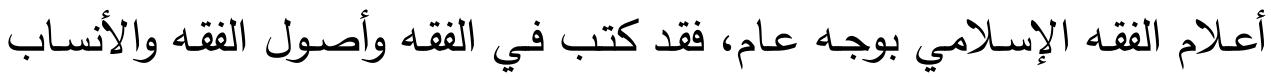

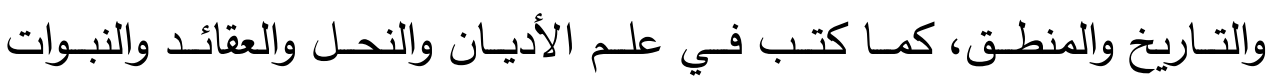
والأخلاق، والحديث والجرح والتعديل ومقارنة الأديان، وكان كذلك الدان أديباً أريباً

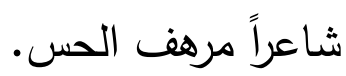

وهو من الأئمة المجتهدين، الذين أحيوا مذهباً من مذاهب السنة وجددوا له

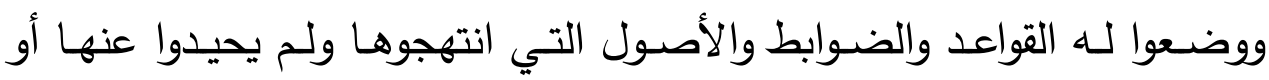
يخالفوها بحال من الأحوال، وقد أثرى الإمام ابن حزم الفقه الإسـلامي بآرائه الفقهية التي تقردت أحياناً واستقلت عن غيرها في المذاهب الأخرى. 
وإني في هذا البحث، أعرض انفراداته في بعض هذه الآراء الفقهية في باب الطلاق، وأبين سبب اختياره لهذا الرأي، والآراء الأخرى التي خالفته، وذلك لك بكل حيادية، وبغير أي ترجيح لرأي على آخر • أهمية الموضوع: تتمثل أهمية هذا الموضوع في عدة أمور، أهمها: ا ـ إن المذهب الظاهري من المذاهب المعتبرة من المذاهب السنية والذي تأسس على يد أحد علماء السنة في العراق وهو داود الظاهري، وأعاد إحياءه ابن حزم في الأندلس.

r بلإِمسام ابـن حزم منزلـة علميـة كبيـرة وملكة فقهيـة فريدة ويعد

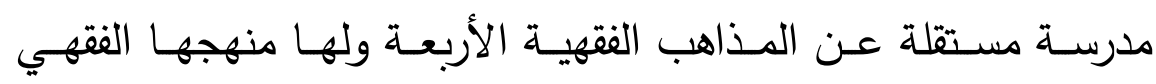

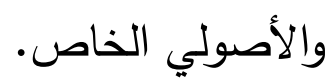

ب. للإِمام ابن حزم آراء فقهية انفرد بها عن غيره من الفقهاء وأئمـة

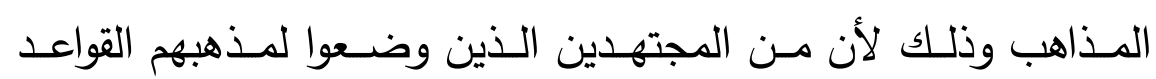
الأصولية الخاصة التي لا يحيدون عنها.

ع. بالرغم من الاختلاف على ابن حزم، وربما يتساوى عدد مؤيديـا مع عدد معارضيه، إلا أن أراءه الفقهية لها اعتبارها في ميزان الفقه. 


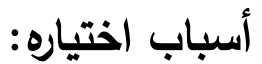

اخترت هذا البحث لعدة أسباب، من أهمها:

ا ـ مكانـة ابن حزم العلميـة والأصـولية والفقهيـة واستقلاله بذهبــ عن المذاهب لفقهية الأربعة المشهورة.

r. اكتسـب الإمـام ابـن حـزم مـن دراسـته للمـذهب الثـافعي روح المجادلة والمنـاظرة والبحث عن الحق، ممـا جعله في إحيائه للمذهب الظاهري يلتزم بعض الآراء الفقهية التي ينفرد بها عن غيره ويؤيدها بالأدلة والبراهين.

r. لابن حزم منهجه الأصولي الذي التزمه في آرائه الفقهية. ـ. إثراء المكتبة الفقهية بهذا البحث الذي استقل بانغرادات ابن حزم

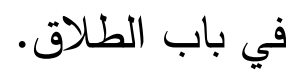

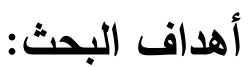

ا ـ التعريف بابن حزم كامام من أئمة المذهب الظاهري.

r. التعريف بالمذهب الظاهري وكيف نشأ. r. بيان جهود ابن حزم في إحياء المذهب الظاهري وتجديده. ع ـ توضيح منهج ابن حزم الأصولي. هـ ذكر انفرادات ابن حزم في باب الطلاق. 


\section{خطة البحث:}

تم تقسيم البحث إلى مقدمـة، وتمهيد، ومبحثين، كل مبحث منهمـا تم تقسيمه إلى عدة مطالب، ثم خاتمة، وذلك على النحو التالي: المقدمة وفيها: - أهمية الموضوع.

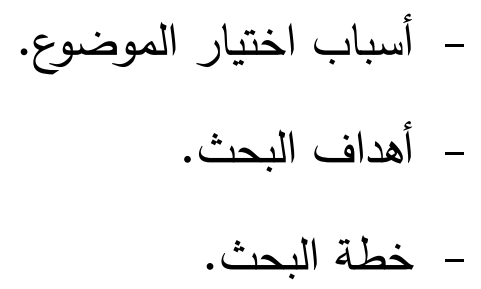
التمهيد: ترجمة ابن حزم الظاهري. المبحث الأول: نشـأة المـذهب الظـاهري وجهود ابـن حزم في

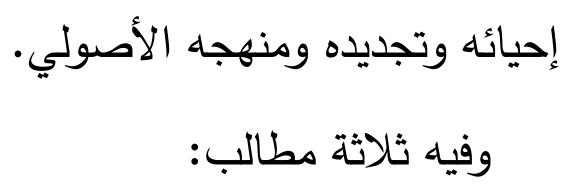

- المطلب الأول: نشأة المذهب الظاهري. - المطلب الثاني: جهود ابن حزم في إحياء المذهب الظاهري

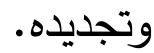
- المطلب الثالث: منهج ابن حزم الأصولي. المبحث الثاني: انفرادات ابن حزم في باب الطلاق.

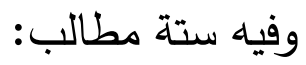


- المطلب الأول: قوله أن الإشهاد شرط لصحة الطلاق وصحة

$$
\text { الرجعة. }
$$

- المطلب الثاني: إنكـاره الإجمـاع بوقوع الطـلاق في الحيض

$$
\text { (الطلاق البدعي). (الب) }
$$

- المطلب الثالث: قوله أن إعلام الزوجـة بالطلاق شرط لصـحة

$$
\text { الطلاق وكذلك إعلام الزوجة بالرجعة شرط لصحة الرجعة. }
$$

- المطلب الرابـع: قولـه أنطـلاق المـريض البـائن مـرض المـوت

$$
\text { كطلاق الصحيح في أثره. }
$$

- المطلب الخامس: قوله أن الطلاق لا يقع إلا بألفاظه مع وجود

- المطلب السادس: قوله أن الحلف بالطلاق والطلاق المعلق لا

يقع بهما الطلاق.

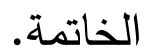

$$
\text { وفيها: }
$$

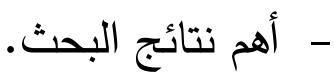

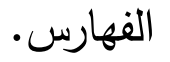

$$
\text { وتشتمل على: - (2) }
$$

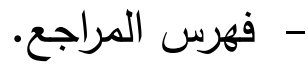

- فهرس الموضوعات. - - 


\section{التمهيد \\ ترجمة ابن حزم الظاهري$$
(\text { ( } 1.7 \varepsilon-99 \varepsilon=\Delta \leq 09-P \wedge \varepsilon)
$$

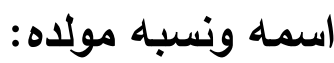

علي بن أحمد بن سعيد بن حزم الظاهري، أبو محمد: عالم الأندلس في

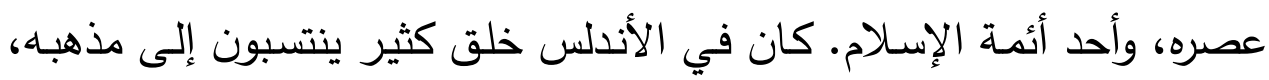
يقال لهم " الحزمية ". ولا بقرطبة .) قـال القاضـي صـاعد بـن أحمد: كتب إلى ابن حزم بخطسه يقول: ولدت بقرطبة في الجانب الشرقي في ربض منية المغيرة، قبل طلوع الثمس آخر ليلة الأربعاء، آخر يوم من رمضان سنة أربع وثمانين وثلاث مائة، بطالع العقرب، وهو اليوم السـابع من نونير • وقال الإمام الذهبي في ترجمته: "الإمسام الأوحد، البحر، ذو الفنون والمعارف، أبو محمد علي بن أحمد بن سعيد بن حزم بن غالب بن صـالح بن خلف بن معدان بن سفيان بن يزيد الفارسي الأصل، ثم الأندلسي القرطبي اليزيدي مولى الأمير يزيد بن أبي سفيان بن حرب الأموي رضي الله عنه المعروف بيزيد الخير، نائب أمير المؤمنين أبي حفص عمر المر

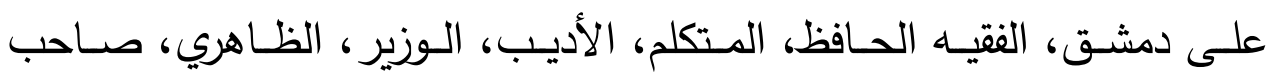
التصانيف، فكان جده يزيد مولى للأمير يزيد أخي معاوية. وكان جده خلف بن

')) انظر : خير الدين بن محمود بن محمد بن علي بن فارس، الزركلي الدمشقي (المتوفى:

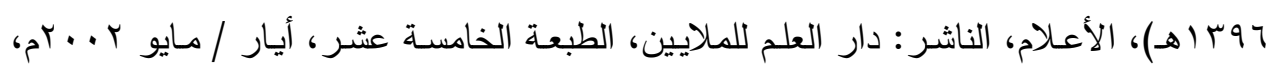

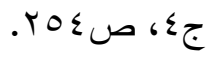


معدان هو أول من دخل الأندلس في صحابة ملك الأندلس عبد الرحمن بن (1) "معاوية بن هشام؛ المعروف بالداخل من أهل قرية الزاوية، من قرى أونبة بالأندلس(r)، ويقول أبو طاهر السلفي: "ولم يحقق ياقوت هذا المكان، قلت: ولعل "أولب" محرفة عن أونبة، وهي على (r). ساحل البرتغال، ومنها البكري أبو عبيد، وفيها توفي الإمام ابن حزم كان جده حزم مـن مـوالي بنـي أميـه، فارسـي الأصـل، اشتخل بالفلسـفة، وكانت له ولأبيه من قبله رياسة الوزارة وتدبير المملكة، فزهد بها وانصرف إلى ميوي العلم والتأليف، فكان من صدور الباحثين، فقيهًا حافظًا يستنبط الأحكام من الكتاب والسنة، بعيدًا عن المصانعة، وانتقد كثيرا من العلماء والفقهاء، فتمالؤوا على بغضه، وأجمعوا على تضليله، وحذروا سلاطينهم من فتتته، ونهوا عوامهم عن الدنو منـه، فأقصـته الملـوك وطاردتـه، فرحل إلـى باديـة ليلـة (مـن بـلاد

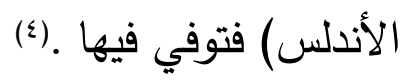

')) انظر : شمس الدين أبو عبد الله محمد بن أحمد بن عثمان بن قَايْماز الذهبي (المتوفى:

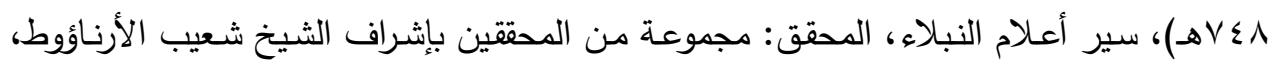

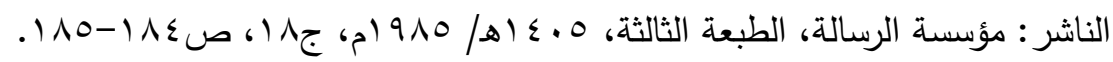

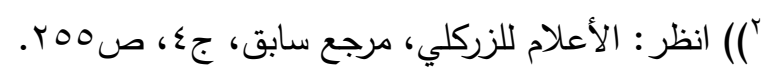

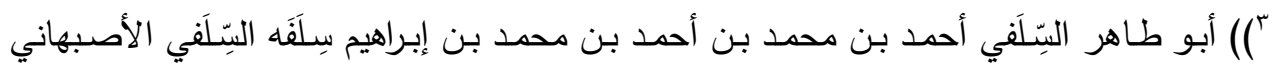

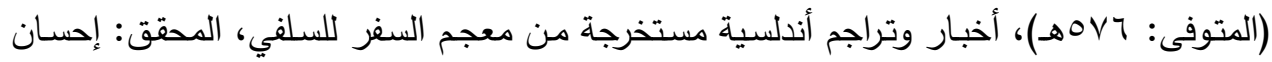

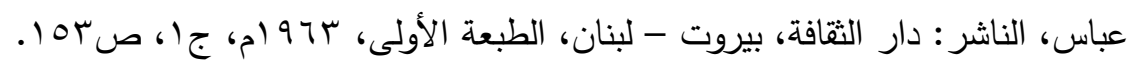

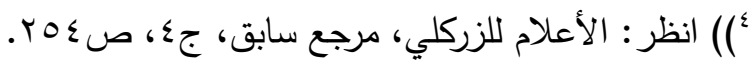


نشأتها:

نشأ في تتعم ورفاهية، ورزق ذكاء مفرطا، وذهنا سيالا، وكتبا نفيسة كثيرة، وكان والده من كبراء أهل قرطبة؛ عمل الوزارة في الدولتة العادريـة، وكذلك وزر أبو محمد في شبيبته، وكان قد مهر أولا في الأدب والأخبار والثـعر ، وفي المنطـق وأجـزاء الفلسـفة، فـأثرت فيـه تـأثيرا ليتـهـ سـلم مـن ذلك، يقول الإمـام الذهبي: "ولقد وقفت له على تأليف يحض فيه على الاعتناء بالمنطق، ويقدمه على العلوم، فتألمت لله، فإنه رأس في علوم الإسـلام، متبحر في النقل، عديم (1) "النظير على يبس فيه، وفرط ظاهرية في الفروع لا الأصسول إن ذلك العيش الرافع الهني، وتلك السعادة الهانئة الناعمة، لم يستمرا لهذا الغـلام الناشـئ ولا لأسـرته، فقد كانت وزارة أبيـه في آخر عهد الأمويين الأول بالأندلس، أي وقت انحلال الأمر من أيديهم وخروجه من سلطانهم إلى سلطان أبي منصسور العامري وأسرته، وابن حزم يقص علينا في حياته الناعمـة هذه كيف كان تبدل النعيم بؤساً، وكيف كان يذوق منه كأسـه المرة في وسط ذلك العيش الحلو، فهو يقول مشيراً إلى مـا نزل بهم وهو في الخامسـة عشرة من عمره(r): "شغلنا بعد قيام أمير المؤمنين هشام المؤيد بالنكبات، وباعتداء أرباب دولته، وامتحنا بالاعتقال والإغرام الفادح والاستتار ، وأرزمت الفتتة وألقت باعها وعمت النـاس وخصـتا، إلى أن تـوفي أبسي الـوزير رحمـه الله ونحن في هذه

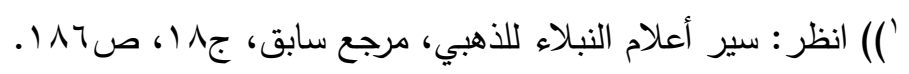

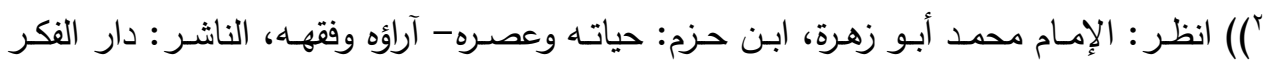

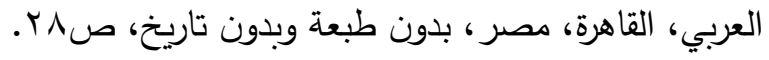


الأحـوال بعـد العصـر يـوم السـبت لليلتين بقيتـا مـن ذي القعـدة عـام اثنتين

(1) " وأربعمائية

طلبه للعلم وشيوخه ونبوغه:

ولد أبو محمد ابن حزم بقرطبة في سنة أربع وثمانين وثلاث مائة، وسمع

في سنة أربع مائة وبعدها من طائفة من العلماء، منهم: يحيى بن مسعود بن

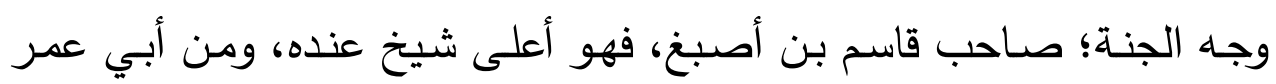
أحمد بن محمد بن الجسور ، ويونس بن عبد الله بن مغيث القاضي، وحمام بن أحمد القاضي، ومحمد بن سعيد بن نبات، وعبد الله بن ربيع التميمي، وعبد

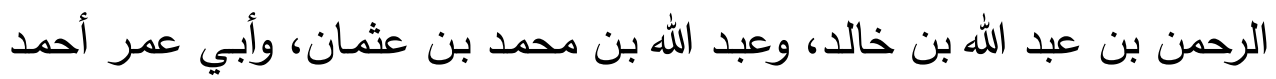

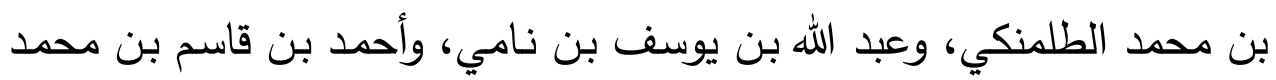

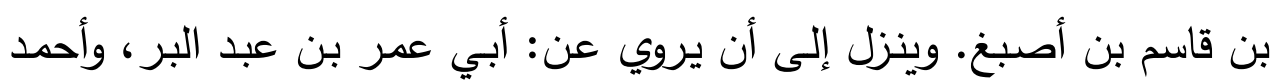

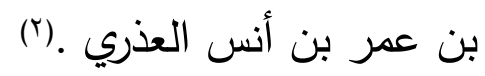
تعلم ابن حزم في حياته الأولى ما يتعلمه أبناء الأكابر من كبار الدولة من حفظ الأشعار، وحفظ القرآن، والخط والكتابة، ولم يكتف أبوه بذلك؛ بل جعل لله رجـلاً تقيـاً وقـوراً حصـوراً يلازمـه، ويجلسـهـ في مجلس الثـيوخ يستمع إليهم، ويتلقى عليهم ما تدركه سنه، ذلك الرجل هو أبو الحسين بن علي الفارسي .(r)

')) أبو محدد علي بن أحمد بن سعيد بن حزم الأندلسي القرطبي الظاهري (المتوفى: 07 ؛هـ)،

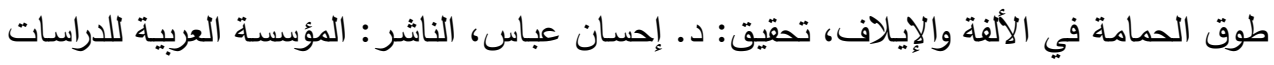

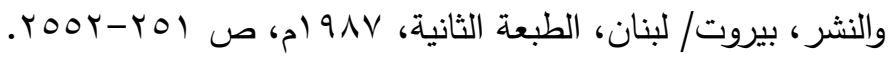

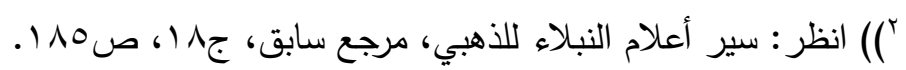

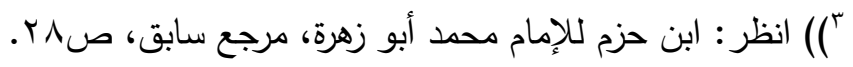


قال أبو بكر محمد بن طرخان التركي: قال لي الإمام أبو محمد عبد الله بن محمد-يعني والد أبي بكر بن العربي-: أخبرني أبو محمد بن حزم أن سبب تعلمه الفقه أنه شهد جنازة، فدخل المسجد، فجلس، ولم يركع، فقال له رجل: قم فصل تحية المسجد. وكان قد بلغ ستا وعشرين سنة. قال: فقدت وركعت، فلما رجعنا من الصـلاة على الجنازة، دخلت المسـجد، فبادرت بالركوع، فقيـل لي: اجلس؛ اجلس، ليس ذا وقت صـلاة -وكان بعد العصر - قال: فانصرفت وقد حزنـت وقلت للأسـاذ الذي ربـاني: دلني على دار الفقيـه أبـي عبد الله بـن دحون. قال: فقصدته، وأعلمته بما جرى، فدلني على "موطأ مالك"، فبدأت بـه عليـه، وتتابعـات قراءتـي عليـهـ وعلى غيـره نحــوا مـن ثلاثـة أعـوام، وبـدأت

(1). بالمناظرة

طلب ابن حزم العلم قبل السياسة، وانصرف إليه انصرافا كاملا، وإن كانت حياته إبان ذلك غير قارة ولا ثابتة فهو ينتقل من قرطبة للتخريب الذي أصابها إلى المريـة، ثم يقبض عليه ويسجن، ثم ينتقل إلى بلنسية، ثم إلى القيروان، وهكذا يعيش في ترحال غير مستقر ، لا يقضي وقته في بلد إلا في الدرس، والاطلاع والبحث والتنقيب، ومهما يكن من أمر، فإنه لم ينصرف انصرافاً كلياً إلى الفقه في صدر حياته العلمية، بل كان يدرس الحديث والأدب والأخبار ، وبعض العلوم العقلية والفلسفية، ومع ذلك كان يناظر ويجادل... وقد اتجه أول ما اتجه إلى الفقه المالكي، فقد كان هو المذهب السائد في الأندلس فوق أنه (ז) المذهب الرسمي للدولة.

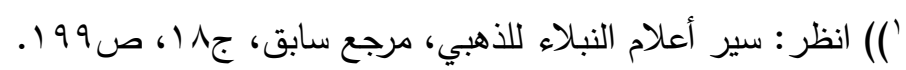

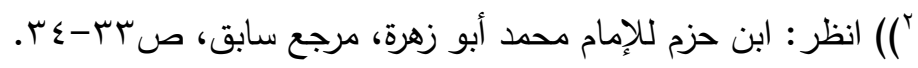


ثم تفقه للشافعي، ثم أداه اجتهاده إلى القول بنفي القياس كله جليه وخفيه، والأخـذ بظـاهر الــص وعمـوم الكتـاب والحـديث، والقـول بـالبراءة الأصـلية، واستصـحاب الحال، وصنف في ذلك كتبا كثيرة، ونـاظر عليه، وبسط لسـانه وقلمه، ولم يتأدب مع الأئمة في الخطاب، بل فجَّجَ العبارة، وسب وجدع، فكان جزاؤه مـن جنس فعله، بحيث إنـا أعرض عن تصـانيفه جماعـة من الأئمـة، وهجروهـا، ونفروا منها، وأحرقت في وقت، واعتتى بها آخرون من العلمـاء، وفتشوها انتقادا واستفادة، وأخذا ومؤاخذة، ورأوا فيها الدر الثمين ممزوجا في الرصف بالخرز المهين، فتارة يطربون، ومـرة يعجبون، ومـن تفرده يهزؤون. وفي الجملـة فالكمـال عزيـز ، وكل أحد يؤخذ مـن قولـه ويترك، إلا رسـول الله (1). صلى الله عليه وسلم قال أبو مروان بن حيان: كان ابن حزم رحمـه الله حامل فنون من حديث وفقه وجدل ونسب، ومـا يتعلق بأذيال الأدب، مـع المشاركة في أنواع التعاليم القديمة من المنطق والفلسفة، وله كتب كثيرة لم يخل فيها من غلط لجراءته في التسور على الفنون لا سيما المنطق، فإنهم زعموا أنه زل هنالك، وضل في سلوك المسالك، وخالف أرسطوطاليس واضع الفن مخالفة من لم يفهم غرضـه، ولا ارتاض، ومال أولا إلى النظر على رأي الشافعي، وناضل عن مذهبه حتى وسم به، فاستهدف بذلك لكثير من الفقهاء، وعيب بالثذوذ، ثم عدل إلى قول أصحاب الظاهر، فنقحه، وجادل عنه، وثبت عليه إلى أن مات، وكان يحمل علمـه هذا، ويجادل عنـه من خالفهه على استرسـال في طباعـه، ومذل بأسراره،

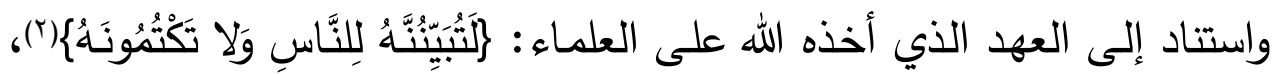

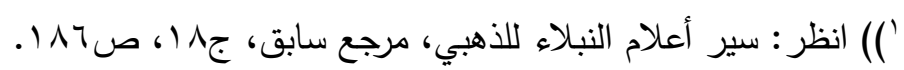

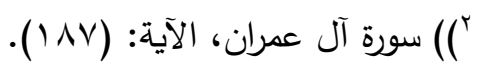


فلم يك يلطف صدعه بما عنده بتعريض ولا بتدربج، بل يصك به من عارضـه صك الجندل، وينشقه انشقاق الخردل، فتنفر عنـه القلوب، وتوقع بـ الندوب، حتى استهدف لفقهاء وقته، فتمالؤوا عليه، وأجمعوا على تضليله، وشنعوا عليه، وحذروا سـلاطينهم مـن فتتــه، ونهـوا عـوامهم عـن الدنو منـه، فطفق الملـوك يقصونه عن قربهم، ويسيرونه عن بلادهم إلى أن انتهوا بـه منقطع أثره: بلدة من بادية لبلة، وهو في ذلك غير مرتدع ولا راجع، يبث علمه فيمن ينتابه من باديـة بلـده، مـن عامـة المقتبسـين مـن أصساغر الطلبـة، الذين لا يخشـون فيـه الملامـة، يحدثهم، ويفقههم، ويدارسهم، حتى كمل من مصنفاته وقر بعير ، لم

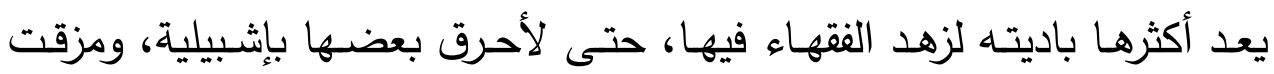
علانية.

يقول الإمـام الذهبي: ولي أنـا ميل إلى أبي محمد لمحبته في الحديث الصـحيح، ومعرفته بـه، وإن كنـ لا أوافقـه في كثير ممـا يقولـه في الرجـال والعللـ، والمسـائل البشـعة في الأصـول والفروع، وأقطع بخطئهـه في غير مـا مسـألة، ولكن لا أكفـره، ولا أضـلله، وأرجـو لـه العفو والمســامحة وللمسـمين.

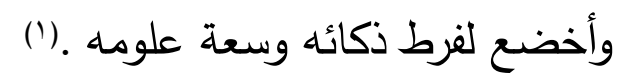

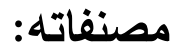

رووا عن ابنـه الفضـل أنـه اجتمـع عنده بخط أبيـه مـن تآليفـه نحو . . ع مجلد، تشتمل على قريب من ثانين ألف ورقة. ومن أشهر مصنفاته: "الفصل فـي الملـلـل والأهــواء والنحـلـ"، و "المحلـى ل، و "جمهــرة الأنسـاب"، و "الناســخ

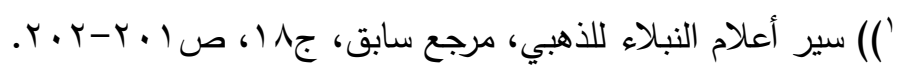


والمنسوخ"، و"حجة الوداع"، و"جوامع السيرة"، و"التقريب لحد المنطق والمدخل

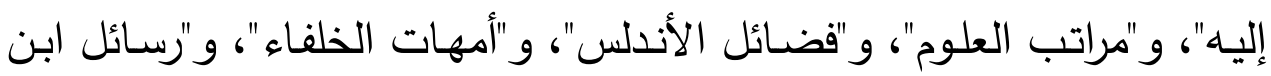

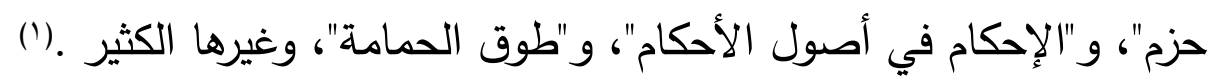
من أقوال العلماء فيه بين المدح والقدح:

كان ينهض بعلوم جمـة، ويجيد النقل، ويحسن النظم والنثر ، وفيها دين

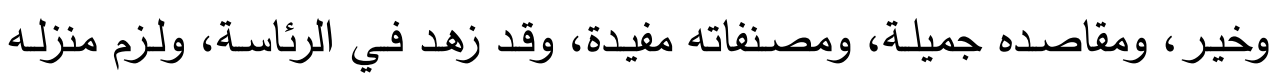
مكبا على العلم، فلا نغلو فيه، ولا نجفو عنه، وقد أثنى عليه قبلنا الكبار . قال أبو حامد الغزالي: وجدت في أسماء الله تعالى كتابا ألفه أبو محمد بن حزم الأندلسي يدل على عظم حفظه وسيلان ذهنه. وقال الإمام أبو القاسم صاعد بن أحمد: كان ابن حزم أجمع أهل الأندلس

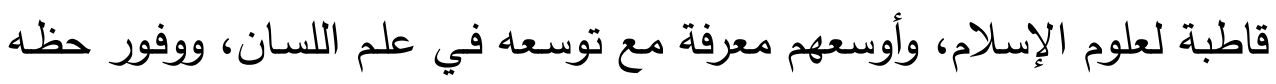

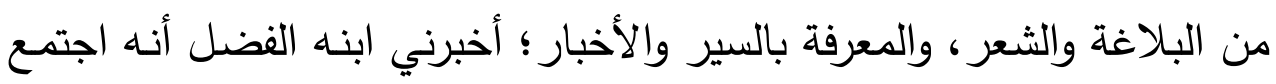

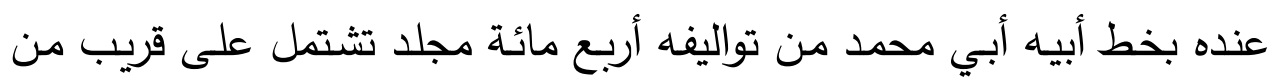
ثمانين ألف ورقة.

قال أبو عبد الله الحميدي: كان ابن حزم حافظا للحديث وفقهه، مستتبطا

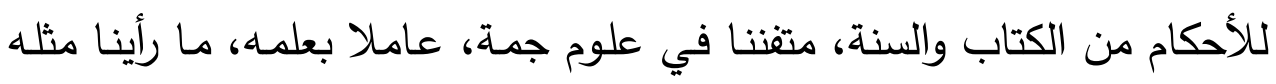

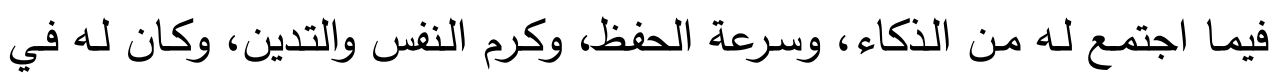

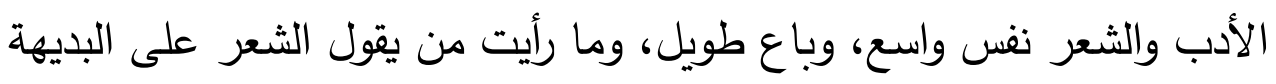
أسرع منه، وشعره كثير جمعته على حروف المعجم.

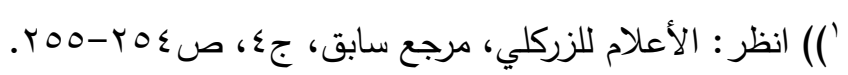


وقال أبو القاسم صاعد: "كان أبوه أبو عمر من وزراء المنصور محمد بن

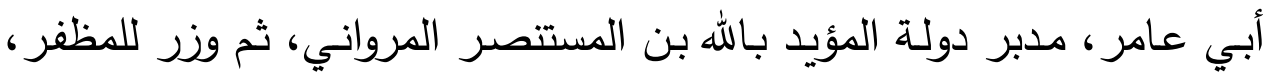
ووزر أبو محمد للمستظهر عبد الرحمن بن هشام، ثم نبذ هذه الطريقة، وأقبل

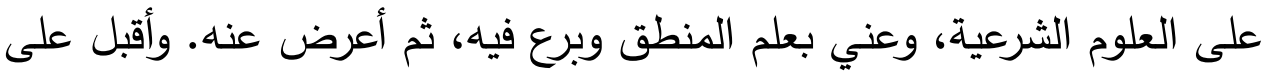

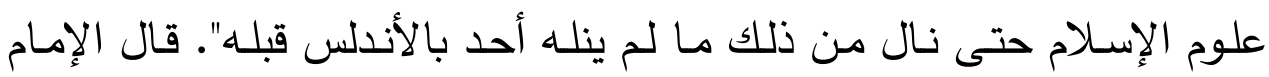
الذهبي: ما أعرض عنه حتى زرع في باطنه أمورا وانحرافا عن السنة. قال اليسع ابن حزم الغـافقي وذكر أبـا محمد فقال: أمـا محفوظهـ فبحر

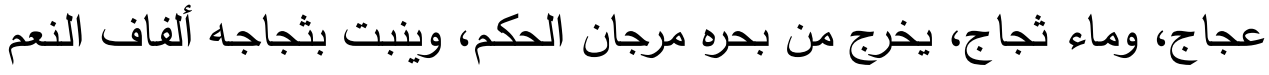

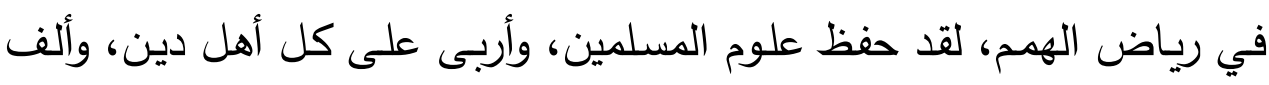

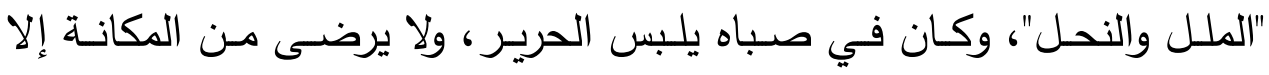

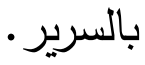
قال الثيخ عز الدين بن عبد السلام: ما رأيت في كتب الإسلام في العلم

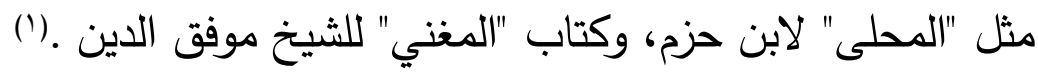
ولقد كان العلماء أشد مناوأة له، وتحريضاً عليه، ولقد كانوا ينكرون عليه ظاهريته، وينكرون عليه خروجه عليهج، فلما تصدى للرد عليهم، نالهم بمثل ما

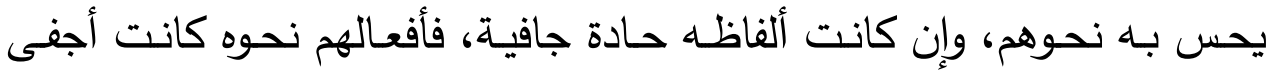
(†). وأحد

ومن هؤلاء: أبو بكر بن العربي، والذي كان ابن حزم هو شيخ أبي أبي بكر بن العربي في العلم، وقد حط أبو بكر بن العربي على أبي محمد ابن حزم

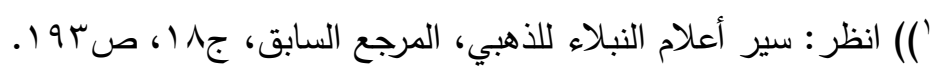

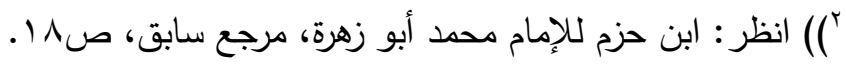


في كتاب "القواصم والعواصم" وعلى الظاهرية، فقال: هي أمة سخيفة، تسورت

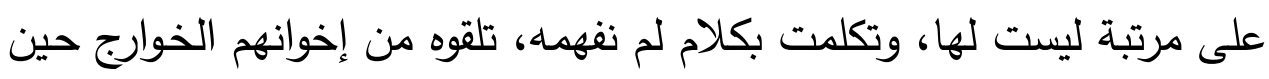

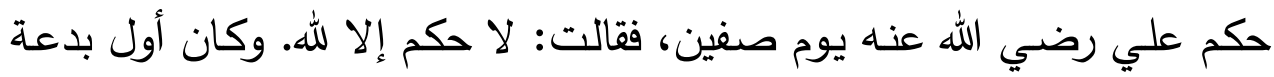

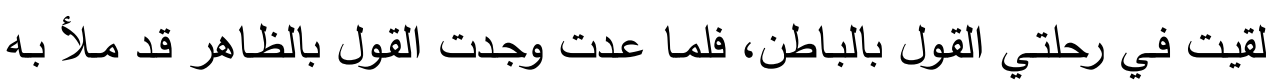

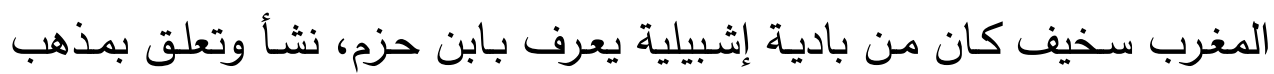

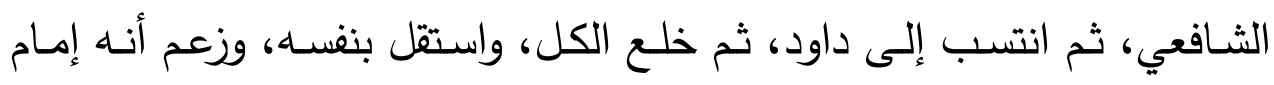

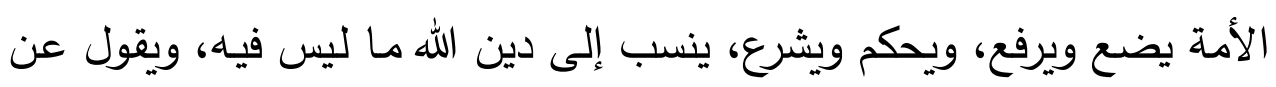

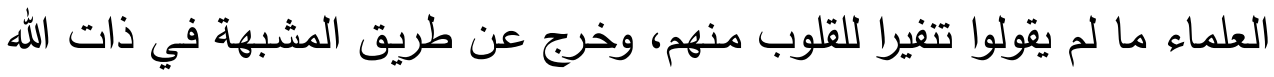
وصفاته، فجاء فيه بطوام.

واتتق كونه بين قوم لا بصر لهم إلا بالمسائل، فإذا طالبهم بالدليل كاعوا،

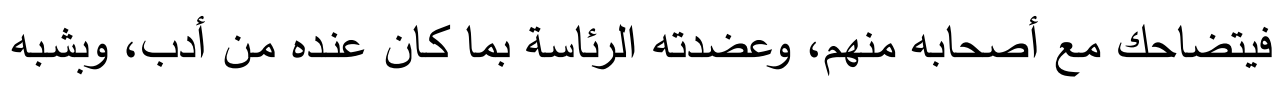

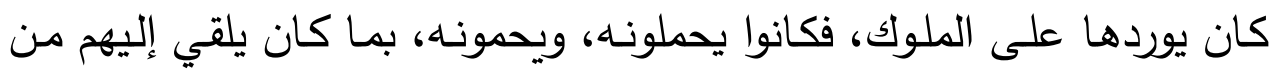

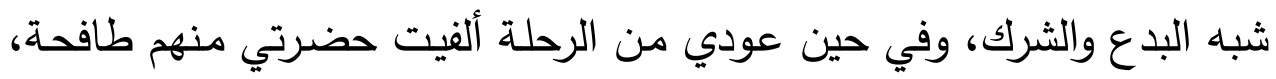

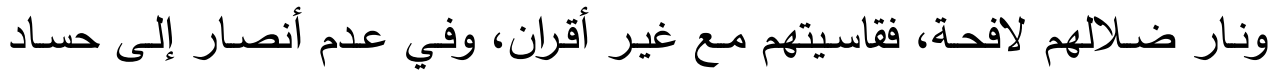

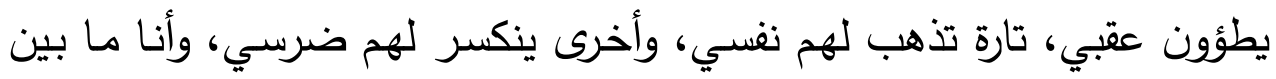

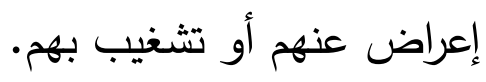

وقد جاءني رجل بجزء لابن حزم سماه (نكت الإسلام)فيه دواهي، فجردت

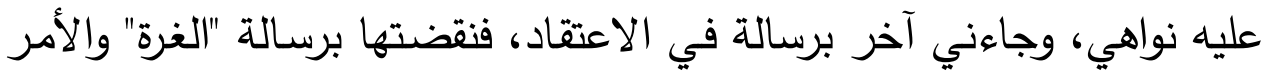

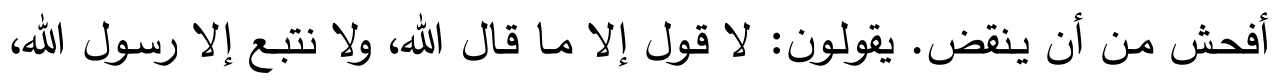

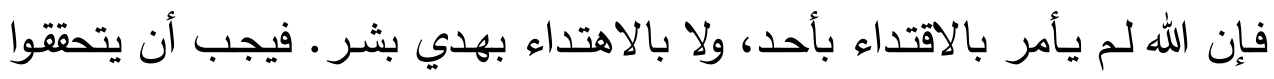

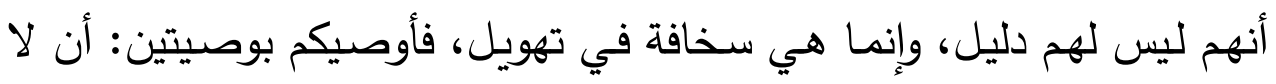


تسـتلوا عليهم، وأن تطـالبوهم بالدليل، فيان المبتد ع إذا استدللت عليـه شـغب عليك، وإذا طالبته بالدليل لم يجد إليه سبيلا.

فأما قولهه: لا قول إلا ما قال الله، فحق، ولكن أرني ما قال. وأما قولهم: لا حكم إلا لله، فغير مسلم على الإطـلاق، بـل مـن حكم الله أن يجعل الحكم لغيره فيما قاله وأخبر به. صـح أن رسول الله صلى الله عليه وسلم قال: اوإذا

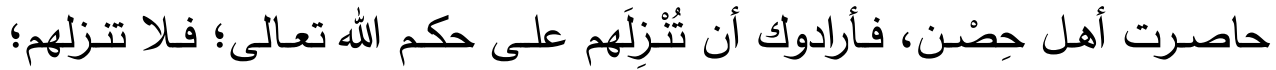
فإنكم لا تدرون ما يَحْكم الله فيهم، ولكن أنزلوهم على حكمكم، ثم اقضوا فيهم بَعْدُ ما شئتم)('). وصسح أنه قال: (عليكم بسنتي وسنة الخلفاء الراشدينه (؟) الحديث.

قال الإمـام الذهبي: "لم ينصف القاضي أبو بكر رحمه الله شيخ أبيه في العلم، ولا تكلم فيه بالقسط، وبالغ في الاستخفاف بـه، وأبو بكر فعلى عظمته في العلم لا يبلغ رتبة أبي محمد، ولا يكاد، فرحمهما الله وغفر لهما" . (َ) وفاته: قال أبو طاهر السلفي: "سنة ست وخمسين وأربعمائة، قال: وهي السـنة التي توفي فيها أبو محمد ابن حزم، وكـان موللده سـنة أربـع وثمانين (๕) وثلاثمائة

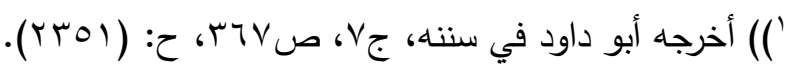

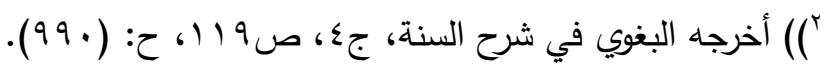

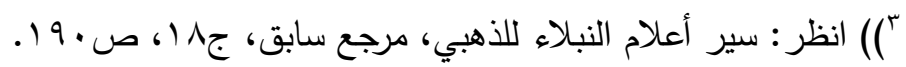

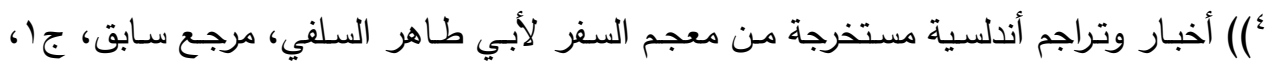


هذا، وقد امتحن ابن حزم لتطويل لسـانه في العلمـاء، وشـرد عن وطنه، فنزل بقريـة لـه، وجرت لله أمور ، وقام عليه جماعة من المالكية، وجرت بينـه وبين أبي الوليد الباجي مناظرات ومنافرات، ونفروا منـه ملوك الناحية، فأقصته الدولة، وأحرقت مجلدات من كتبه، وتحول إلى بادية لبلة في قرية، وقد قال أبو العباس ابن العريف: كان لسان ابن حزم وسيف الحجاج شقيقين. قال أبو الخطاب ابـن دحيـة: "كان ابـن حزم قد بـرص من أكل اللبـان، وأصابه زمانة، وعاش ثنتين وسبعين سنة غير شهر". وقال القاضـي صـاعد بن أحمد: ونقلت من خط ابنه أبي رافح، أن أباه توفي عشية يوم الأحد لليلتين بقيتا من شعبان، سنة ست وخمسين وأربع مائة،

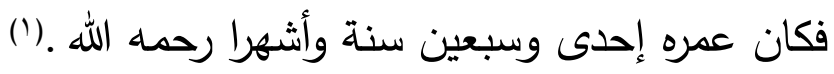

') سير أعلام النبلاء للذهبي، مرجع سابق، ج^( ، ص (اب. 


\section{المبحث الأول}

نشأة المذهب الظاهري وجهود ابن حزم في إحيائه وتجديده ومنهجه الأصولي

إن العمل بالظاهر باعتباره مذهبا فقهيا واتجاها من اتجاهات التعامل

مع الألفاظ والنصوص فهما وتتزيلا، باعتباره مندرجا ضمن مدرسة أصولية لها أعلامها وخصائصها؛ فإن العمل بالظاهر بحسب هذا الاعتبار يكاد المؤرخون والباحثون يجمعون على أن مؤسسه الأول هو الإمام داود بن علي الأصفهاني والذي سمي داود الظـاهري، لبعثه أول نـواة لكيـان المدرسـة الظاهريـة ولشهرته

(البالغة في أخذه بظواهر النصوص . (1) والاتجاه إلى الظاهر معناه الوقوف عند حدود الألفاظ التي وردت من

(؟).الشارع، دون عناية بالبحث عن علتها ومقاصدها وتتقق جميع المصادر الأندلسية والمغربية على أن أول من أسس لمذهب الظاهر بالأندلس وعرف به أهله، ونقله إليها من المشرق، هو عبد الله بن قاسم بن هلال بن يزيد بن عمران القيسي أبو محمد الأندلسي، من أهل قرطبة، فقيه جليل، كان مالكيا بحكم البيئة والنشأة، لكنه ما لبث أن رحل إلى المشرق ودخل العراق، ولقي أبا سليمان داود بن علي الأصفهاني الظاهري، إمام أهل الظاهر،

') أبو بكر أحمد بن علي بن ثابت بن أحمد بن مهدي الخطيب البغدادي (المتوفى: بآـهـ)،

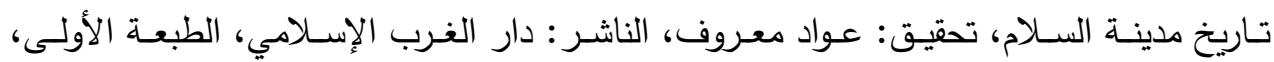

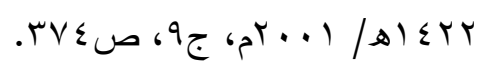

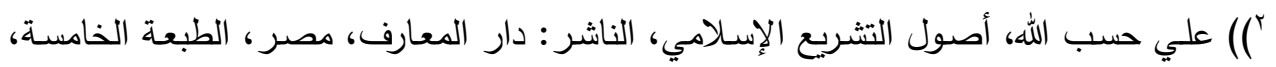
(IT) 
فكتب عنه كتبه كلها وأدخلها الأندلس واجتها في نشرها، ونشر مذهب الظاهر بها، فأخلت باه عند علماء وقته بسبب تمكن المذهب المالكي من الناس، فنظر في فقه مالك رحمه الله نظرا حسنا، غير أن علم داود ظل الأغلب عليه فكان (1). يميل على القول بالظاهر والمدرسـة الظاهريـة كـأي اتجـاه فكري أو مـذهب فقهي، لهـا خصائصـها العامة، وسماتها الإجمالية في فهم الألفاظ والنصوص ومعالجة أوضاع المكلف وأحوال الحياة بصفة عامة، وهذه الخصائص إطلاقا تتفق جميعها على خاصية الأخذ بالظساهر، أي الأخذ بظواهر النصـوص وهي خاصسية امتازوا بها عن سائر المذاهب الأخرى، وهذا الذي أعطاهم اسم الظاهرية.(؟) وبـدأت بـذور المـذهب الظـاهري تتبـت في الأندلس، حتى كـان للمذهب الظاهري في القرن الرابع الهجري في الأندلس مقام ودعاة ومدافعون، ولذلك وجد ابن حزم من تلقى عليه ذلك المذهب، وقد تسلم ابن حزم المذهب الظاهري في أشد أوقات الحاجة إلى مثل شخصيته، فكأن الله عوض ذلك المذهب الذي خبـا نجمـه في الشـرق، بأن قضــت إرادتـه أن يقف ابـن حزم لنصـرته ونشـره وتأييده، وإحيائه دن جديد، وتهذيب أصوله وخصائصهه . (r)

')) توفيق الغلبزوري، ابن حزم الأندلسي، الناشر : المنهج والمعرفة، بدون طبعة وبدون تاريخ، ص ص

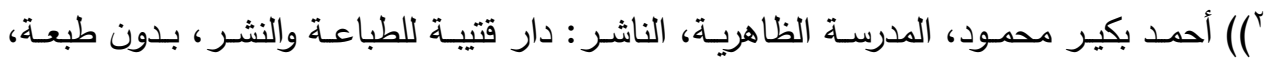

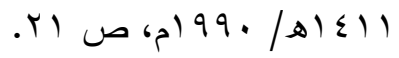

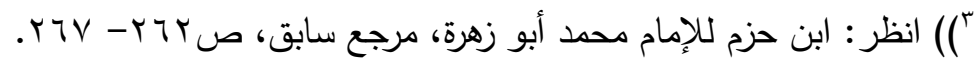




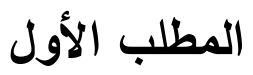

\section{نشأة المذهب الظاهري}

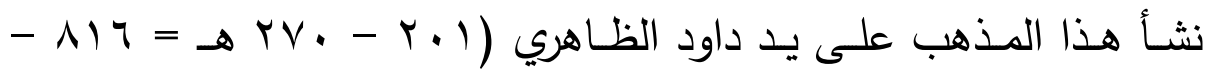

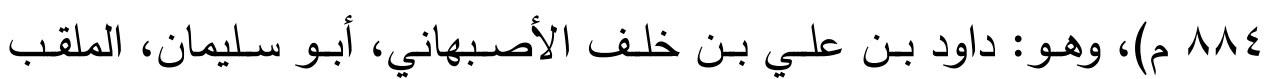

بالظاهري، أحد الأئمة المجتهدين في الإسلام.

تتسب إليه الطائفة الظاهريـة، وسميت بذلك لأخذها بظاهر الكتاب والسنة وإعراضها عن التأويـل والرأي والقياس، وكان داود أول من جهر بهذا القول، وهو أصبهاني الأصل، من أهل قاشـان (بلدة قريبة من أصبهان) ومولده في الكوفة، سكن بغداد، وانتهت إليه رياسة العلم فيها.

قـال ابن خلكـان: قيـل: كـان يحضـر مجلســ كل يـوم أربـع مئسة صـاحب

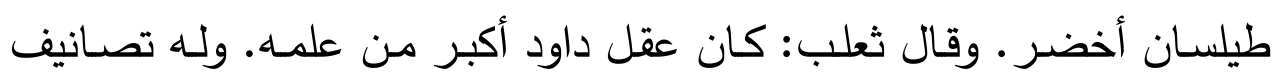
أورد ابن النديم أسماءها في زهاء صفحتين. توفي في بغداد .) (1) وصفه الإمام الذهبي في سير أعلام النبلاء بأنه: "الإمام، البحر، الحافظ، العلامة، عالم الوقت، أبو سليمان البغدادي، المعروف بالأصبهاني، مولى أمير المؤمنين المهدي، رئيس أهل الظاهر". قال أبو بكر الخطيب: صنف الكتب، وكان إماما ورعا ناسكا زاهدا، وفي كتبه حديث كثير، لكن الروايـة عنـه عزيزة جدا. حدث عنـه: ابنـه؛ أبو بكر محمد بـن داود، وزكريـا السـاجي، ويوسـف بـن يعقوب الداوودي، وعبـاس بن أحمد المذكر، وغيرهم.

') (') الأعلام للزركلي، مرجع سابق، جr، صس س. 
قال أبو محمد بن حزم: إنما عرف بالأصبهاني، لأن أمها أصبهانية، وكان

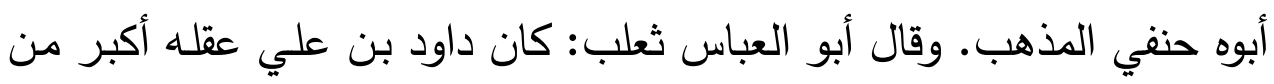
علمه.

وقال قاسم بن أصبخ الحافظ: ذاكرت ابن جرير الطبري وابن سريج في

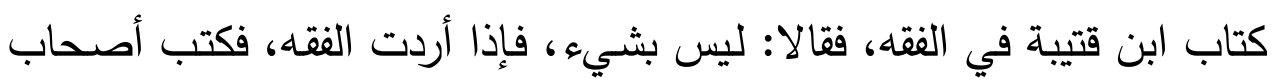

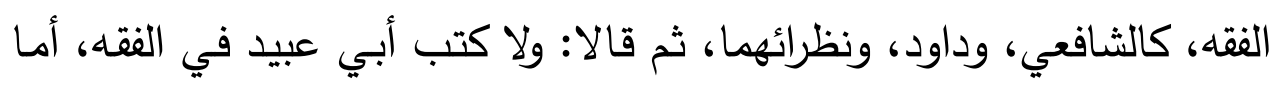

$$
\text { ترى كتابه في (الأموال) مع أنه أحسن كتبه؟ }
$$

وقـال ابن حزم: كـان داود عراقياً، كتب ثمانيـة عشـر ألف ورقـة، ومـن

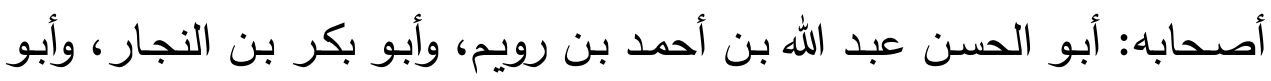

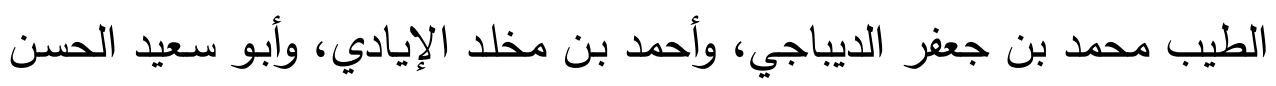

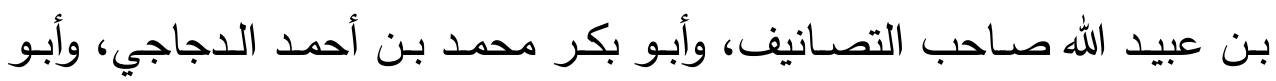
نصر السجستاني..، ثم سرد أسماء عدة من تلامذته.

قال ابن كامل: مات داود في شهر رمضان، سنة سبعين ومائتين .) وذكره ابن خلكان في كتابه "وفيات الأعيان"؛ فقال مثنياً عليه: أبو سليمان بن علي بن خلف الأصبهاني الإمام المشهور المعروف بالظاهري؛ كان زانيات الاهداً

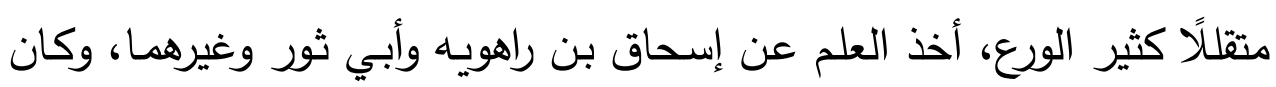

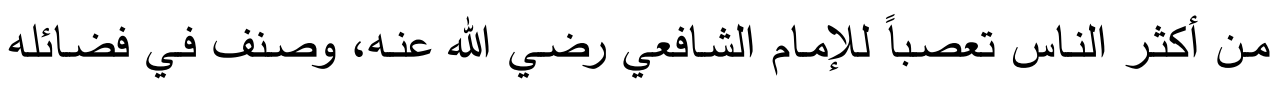
والثناء عليه كتابين، وكان صـاحب مذهب مستقل، وتبعـه جمع كثير يعرفون

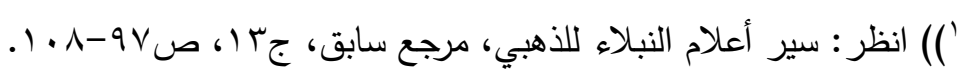


بالظاهريـة، وكان ولـده أبو بكر محمد على مذهبـه وانتهـت إليـه رياسـة العلم

$$
\text { (1). ب بغداد }
$$

مذاهب العلماء في الاعتداد بالمذهب الظاهري:

للعلماء قولان في الاعتداد، بخلاف داود وأتباعه: فمن اعتد بخلافهم، قال: ما اعتدادنا بخلافهم لأن مفرداتهم حجة، بل لتحكى في الجملة، وبعضها سائخ، وبعضـها قوي، وبعضـها سـاقط، ثم مـا تفردوا بـه هو شـيء من قبيل مخالفـة الإجماع الظني، وتتدر مخالفتهم لإجماع قطعي، ومن أهدرهم، ولم يعتد بهم، لم يعدهم في مسائلهم المفردة خارجين بها من الدين، ولا كفرهم بها، بل يقول: هؤلاء في حيز العوام، أو هم كالثيعة في الفروع، ولا نلتقت إلى أقوالهم، ولا ننصب معهم الخلاف، ولا يعتتى بتحصيل كتبهم، ولا ندل مستقتيا من العامة عليهم، وإذا تظــاهروا بمسـألة معلومــة الـبطلان، كمسـح الـرجلين، أدبنــاهم،

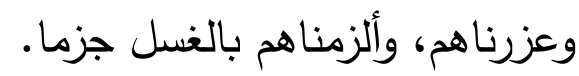

قـال الأسـتاذ أبـو إسـحاق الإسـراييني: قـال الجمهور : إنهم كيعني نفـاة القياس- لا يبلغون رتبة الاجتهاد، ولا يجوز تقليدهم القضاء. ونقل الأستاذ أبو منصور البغدادي، عن أبي علي بن أبي هريرة، وطائفة من الثافعية: أنه لا اعتبار بخلاف داود، وسـائر نفاة القياس، في الفروع دون الأصسول. وقال إمام الحرمين أبـو المعـالي: الذي ذهب إليـه أهل التحقيق: أن منكري القيـاس لا يعدون من علماء الأمـة، ولا من حملة الشريعة؛ لأنهم معاندون مباهتون فيما

') أبو العباس شمس الدين أحمد بن محمد بن أبي بكر بن خلكان، وفيات الأعيان وأنباء أبناء

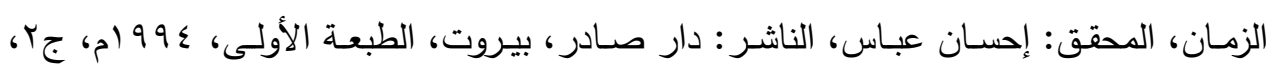

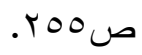


ثبـت استفاضــة وتـواترا، لأن معظم الثـريعة صـادر عـن الاجتهـاد، ولا تفـي النصوص بعشر معشارها، وهؤلاء ملتحقون بالعوام.

قال الإمـام الذهبي: هذا القول مـن أبي المعـالي أداه إليـه اجتهاده، وهم فأداهم اجتهادهم إلى نفي القول بالقياس، فكيف يرد الاجتهاد بمثله، وندري بالضرورة أن داود كان يقرئ مذهبه، ويناظر عليه، ويفتي بـه في مثل بغداد، وكثرة الأئمة بها وبغيرها، فلم نرهم قاموا عليه، ولا أنكروا فتاويه ولا تدريسه، ولا سـعوا في منعـه مـن بثـه، وبالحضـرة مثل إســاعيل القاضـي شيخ المالكيـة، وعثمان بـن بشـار الأنمـاطي شيخ الثـافعية، والمـروذي شيخ الحنبليـة، وابني الإمام أحمد، وأبي العباس أحمد بن محمد البرتي شيخ الحنفيـة، وأحمد بن أبي عمران القاضي، ومثل عالم بغداد إبراهيم الحربي، بل سكتوا له، حتى لقد قال قاسم بن أصبغ: ذاكرت الطبري -يعني: ابن جرير - وابن سريج، فقلت لهما: كتاب ابن قتيبة في الفقه، أين هو عندكما؟ قالا: ليس بشيء، ولا كتاب أبي عبيد، فإذا أردت الفقه فكتب الثافعي، وداود، ونظرائهما. ثم كان بعده ابنه أبو بكر ، وابن المغلس، وعدة من تلامذة داود، وعلى أكتافه مثل: ابن سريج شيخ الشافعية، وأبي بكر الخلال شيخ الحنبلية، وأبي الحسن الكرخي شيخ الحنفيـة، وكان أبو جعفر الطحاوي بمصر، بل كانوا يتجالسون ويتناظرون، ويبرز كل منهم بحججه، ولا يسعون بالداودية إلى السلطان، بل أبلغ من ذلك، ينصبون معهم الخلاف في تصانيفهم قديما وحديثا، وبكل حال فلهم أشياء أحسنوا فيها، ولهم مسائل مستهجنة، يشغب عليهم بها، وإلى ذلك يشير الإمام أبو عمرو بن الصلاح، حيث يقول: الذي اختاره الأستاذ أبو منصور ، وذكر أنه الصحيح من المذهب، أنه يعتبر خلاف داود. 
ثم قال ابن الصلاح: وهذا الذي استقر عليه الأمر آخرا، كما هو الأغلب

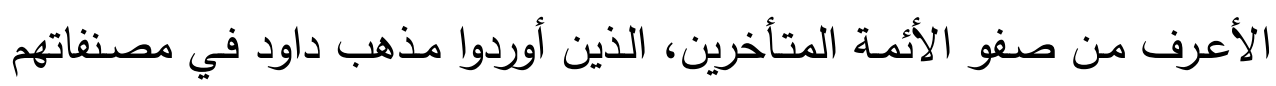

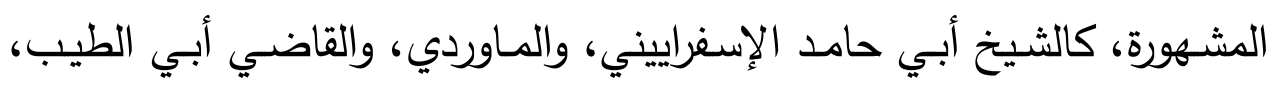

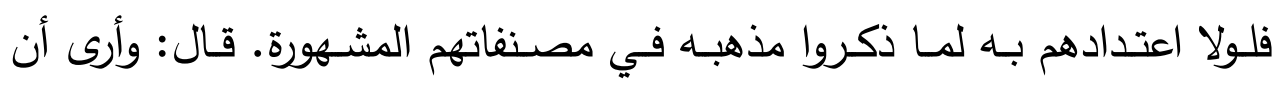

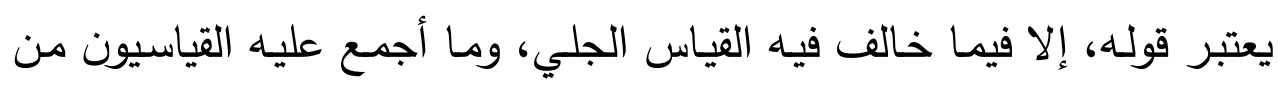

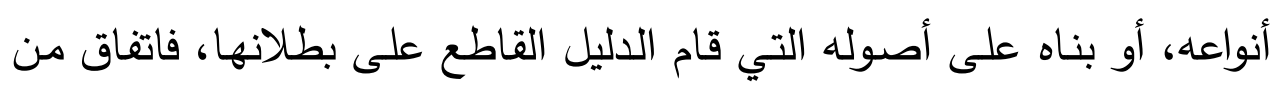

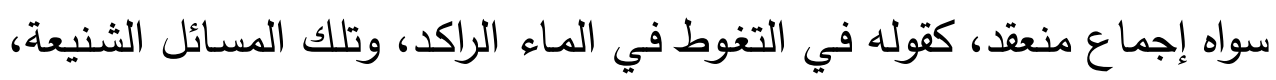

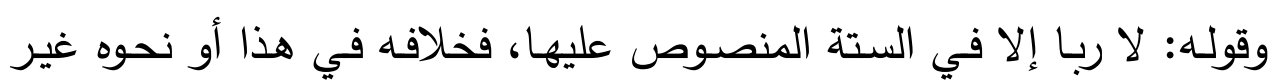
معتد به، لأنه مبني على ما يقطع ببطلانه.

قال الإمام الذهبي: لا ريب أن كل مسألة انفرد بها، وقطع ببطلان قوله

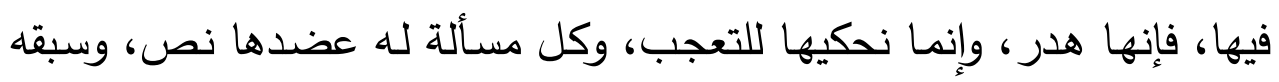

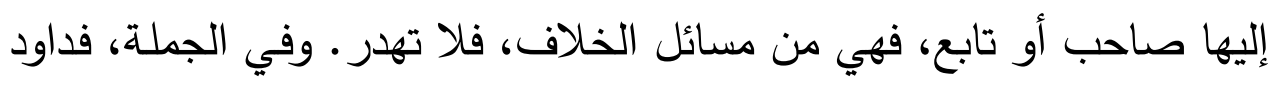

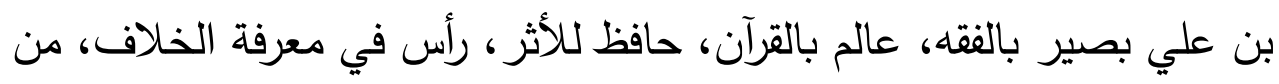

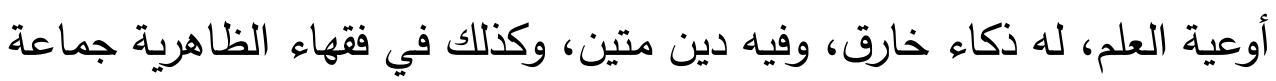
لهم علم باهر ، وذكاء قوي، فالكمال عزيز، والله الموفق.

قال الإمام الذهبي في ختام حديثه عن المذهب الظاهري ومؤسسه أبي داود: "ونحن فنحكي قول ابن عباس في المتعة، وفي الصرف، وفي إنسام إنكار

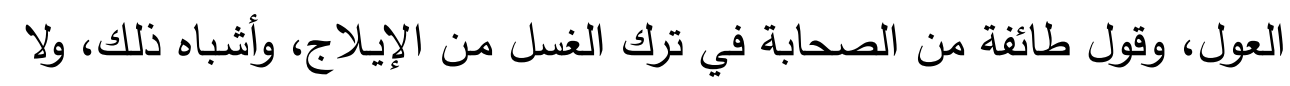

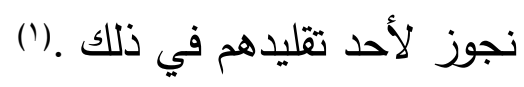

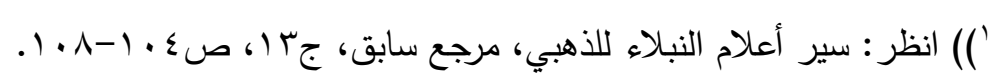




\section{خصائص المذهب الظاهري:}

ا ـ الأخذ بظواهر النصوص وهي خاصية امتازوا بها عن سـئر

المذاهب الأخرى وهذا الذي أعطاهم اسم الظاهريـة، أمـا نفيهم القياس

فقد يوافقهم فيه بعض العلماء من المذاهب الأخرى.

r. نفـيهم للقيـاس والاستحسـان والمصـالح المرسـلة وســـ الـذرائع

والإجماع وعمل أهل المدينة.

ז. المعتمد عند الظاهرية أصلا في الشرع هو إجماع الصحابة.

ــ العمل بخبر الآحاد في العقائد والأعمال.

(1). منع التقليد مطلقا على الخاصة والعامة

')) انظر : نسيلة ناجي، ابن حزم: آراؤه ومنهجه ومذهبه الفقهي، رسالة ماجستير ، تخصص تاريخ

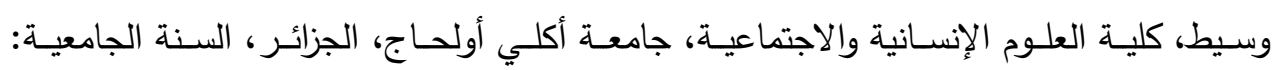

$$
\text { . }
$$




\section{المطاب الثاني}

\section{جهود ابن حزم في إحياء المذهب الظاهري وتجديده}

اختار ابن حزم المذهب الظاهري لأنه ليس في هذا المذهب مقلداً، لا في

المذهب، ولا في غيره، إنه مذهب الكتاب والسنة وإجماع الصحابة، وليس لأحد فيـه أن يقلد أحداً، ولا شك أن ذلك يتفق مـع نزعـة ابن حزم الحر الذي يريد دائما أن يحلق في سماء الكتاب والسنة من غير أي حواجز من الفكر تقف

\section{(') دون ذلك.}

وسبق وبينا أن ابن حزم قد تلقى الفقه المسالكي في بداية دراسته الفقهية، كثأن أهل الأندلس بوجه عام، وذوي المناصب منهم بوجه خاص، وذلك لأن المذهب المسالكي كان هو المذهب السـائد في الأندلس، ثم عدل عن المذهب المـالكي إلى المـذهب الثـافعي، الذي أثر في فكره، فاكتسـب روح المجادلـة والمناظرة للبحث عن الحق، كما أن رسوخ قدمها في علم الحديث ومحبته لله جعلته لا يبتغي بغيره بديلا، ولا يرضى عنـه تحويلا، فكل ما وافق الدليل فهو حق، وكل ما خالف فهو باطل لا عبرة به، إضافة إلى ورع ابن حزم وخشيته أن ينسب إلى دين الله مـا ليس منـه برأي أو قياس أو استحسـان، فأقبل على بلى إسلى ظاهر النصوص وأدبر عما سواها، فأقبل على المذهب الظاهري، وأحياه في

(r). (الأندلس

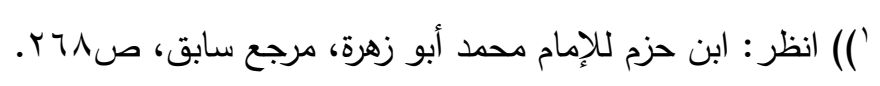

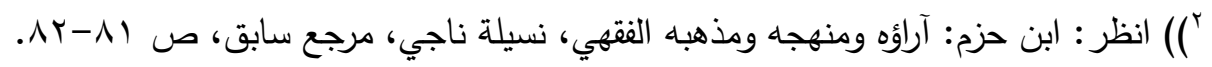


ويرى العلماء أن لابن حزم فقه له لون خاص امتاز بها، وله آراء فقهية ليست في فقه الأئمة الأربعة ولا غيرهم، وهو يتفق في كثير من الأحوال مع المنقول، وله من الآراء الفقهية ما يخالف بها الأربعة، وجمهور الفقهاء، لذلك كان لا بد من دراسته على هذا الأسـاس، وهو أنه لون فقهي مخالف لما كان عليـه الأئمسة الأربعـة، وهو يخالفهم في مسـائل تعد في مرتبـة المجمع عليها بينهم، وكما يخالفهم في الفرع، يخالفهم في منهاج الاستتباط، فهم يعتمدون في استتباطهح على الكتاب والسنة والإجماع والرأي، ويختلفون في منهاج الرأي ما بين مضيق فيها وموسـع، أمـا ابن حزم، فقد اعتمد فقط على الكتاب والسنة والإجماع، بل غنه يصرح بأنه لا يصح لأحد أن يقلد أحدا، ولو كان صحابيا، أما الأئمة الأربعة فقد اتفقوا على القول برأي الصحابي، قال ذلك أبو حنيفة ومالك، وكتبه الثـافعي في رسالته، وأخذ به أحمد، وكان ذلك من عمد الفقه

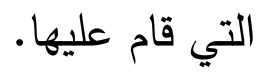
وبذلك خالف ابن حزم في منهجـه مناهج الأئمسة الأربعـة في استتباطهم، وحمل فقهه اسم الفقه الظاهري، لأنـه لم يعتمد إلا على ظاهر الكتاب والسنتة، حيـث بـذل جهـده في إحيـاء المـذهب الظـاهري وتوضـيح أصـوله وتهذيب خصائصسـه، وذلـك مـن خــلال منهجــه الأصــولي الـذي اعتمــده فـي فقهــا

(1). (الظاهري

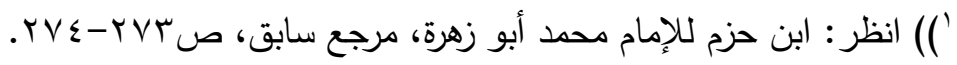




\section{المطاب الثالث}

\section{منهج ابن حزم الأصولي}

قد حدد ابن حزم منهجه الأصولي الظاهري في كتابه "النبذة الكافية في أصـول الفقـه"، وهو المـنهج الذي يتماشـى مـع أصـول المنهج الظـاهري بوجـهـ عام، ويمكن تلخيصه في النقاط التالية:

ا- إن أهـل العصـر الذي إجمـاعهم هـو الإجمـاع الذي أمـر الله تعـالى باتباعهم الصحابة رضي الله عنهم فقط، ونفى جواز أن يكون الإجماع المأمور به شرعاً هو إجماع كل عصر من أول الإسلام إلى انقضاء العالم ومجيء يوم

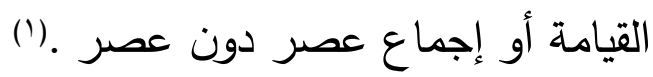
r- مـن قـال أن الإجمـاع إجمـاع أهل المدينـة لفضـلها ولأن أهلهـا شهـوا نزول الوحي فقول خطأ من وجوه: أحدها: أنها دعوى بـلا برهان، والثاني: أن إن فضل المدينة باق بحسبه والغالب على أهلها اليوم الفسق بل الكفر من غالية الروافض، والثالث: أن الذين شهدوا الوحي إنما هم الصحابة رضي الله عنهم لا من جـاء بعدهم مـن أهل المدينـة وعن الصـحابة أخذ التابعون من أهل كل مصـر ، والرابـع: أن كـل خـلاف وجـد في الأمــة فهـو موجـود في المدينـة، والخامس: أن الخلفاء الذين كانوا بالمدينة لا يخلو حالهم من أحد وجهين لا ثالث لهما: إما أن يكونوا قد بينوا لأهل الأمصار من رعيتهم حكم الدين، أو لم يبينوا، فإن كانوا قد بينوا لهم الدين فقد استوى أهل المدينة وغيرهم في ذلك، وان ')) انظر : أبو محمد علي بن أحمد بن سعيد بن حزم الأندلسي القرطبي الظاهري (المتوفى:

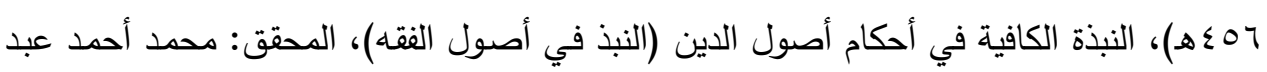

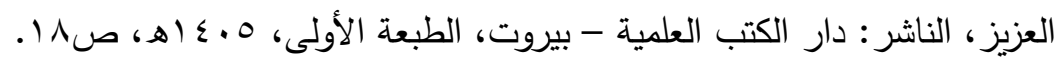


كانوا لم يبينوا لهم فهذه صفة سوء قد أعاذهم الله تعالى منها، فبطل قول هؤلاء بيقين، والسادس: أنه إنما قال ذلك قوم من المتأخرين ليتوصلوا بذلك إلى تقليد

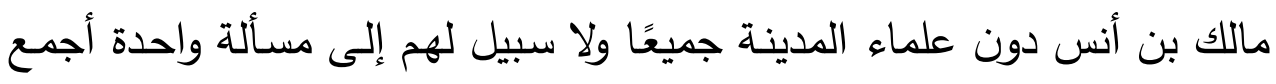
عليها جميع فقهاء أهل المدينة المعروفون من الصحابة والتابعين خالفهم فيها

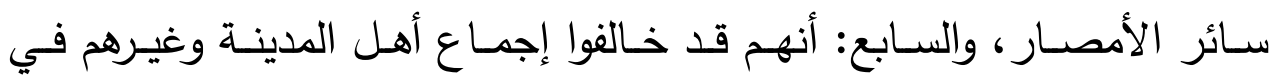

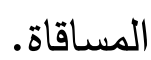

r- إذا اختلف الناس على قولين فصاعدا، وصـح النص شاهدا لأحدهما

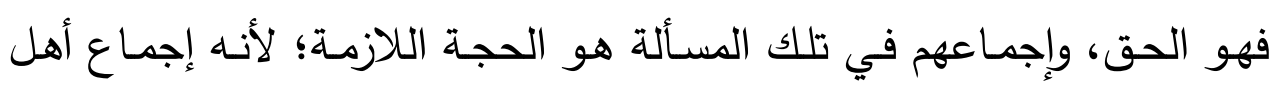

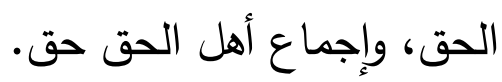

ع- قبول خبر الواحد إذا صح، وذلك لأنه لا يحل أن نخبر عن الله تعالى

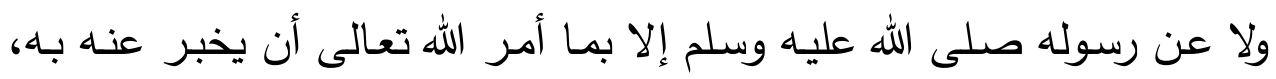

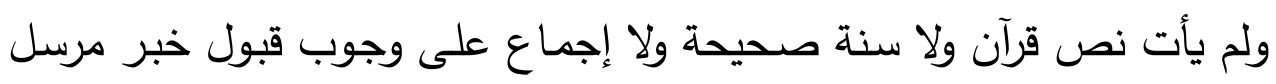

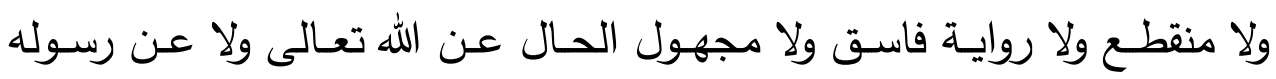

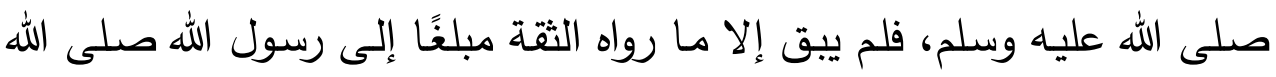

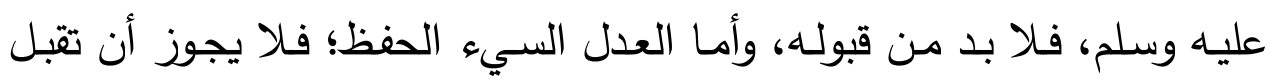
(1). روايته

0- لا يحل لأحد أن يحيل آية عن ظاهرها، ولا خبرا عن ظاهره؛ لأن الله

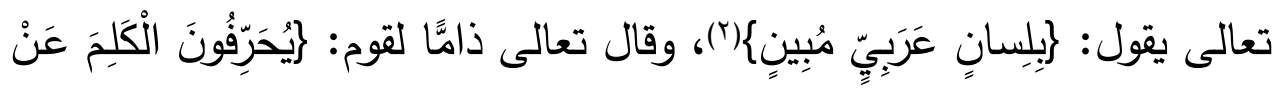

')) انظر : النبذة الكافية في أحكام أصول الدين (النبذ في أصول الفقه)، لابن حزم، المرجع

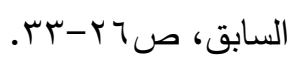

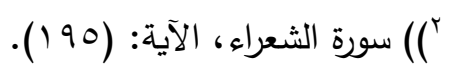


مَواضِـعِهِ|\{(')، ومـن حسال نهَّا عن ظـاهره في اللغـة بغير برهـان من آخر أو إجماع فقد ادعى أن النص لا بيان فيه، وقد حرف كلام الله تعالى ووحيـ إلى نبيه صلى الله عليه وسلم عن موضعه، وهذا عظيم جدَّا.

צ- إذا وقعت اللفظـة في اللغـة على معنيين فصـاعدًا وقوعًا مستويًا، لـم يجز أن يقتصر بها على أحدهما بلا نص ولا إجماع، لكن يحمل على كل ما يقع عليه في اللغـة، وإذا جاء في القرآن لفظ عربي منقول عن موضـعه في اللغـة إلى معنى آخر كالصـلاة والزكاة والصـوم والحـ؛ فإن هذه ألفاظ لغويـة نقلت إلى معانٍ شرعية لم تكن العرب تعرفها قبل ذلك؛ فهذا ليس مجازا؛ بل

$$
\text { هي تسمية صحيحة. }
$$

V- ولا يحل أن يقال في آية أو خبر صحيح هذا منسوخ؛ لأن قائل ذلك مسقط لطاعة ذلك النص إلا بنص آخر يبين أن هذا منسوخ أو إجماع متيقن على نسخه، وإلا فلا يقدر أحد على استعمال النص، وأمـا ما دام يمكننا جمع النصوص من القرآن والسـنة فـلا يجوز تركهما ولا ترك أحدهما؛ لأن كليهما (r) سواء في وجوب الطاعة، وليس بعضها في وجوب الطاعة أولى من بعض

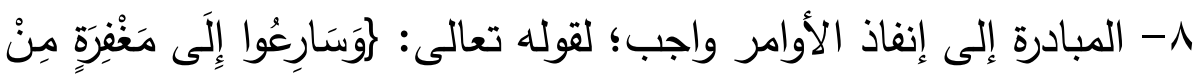

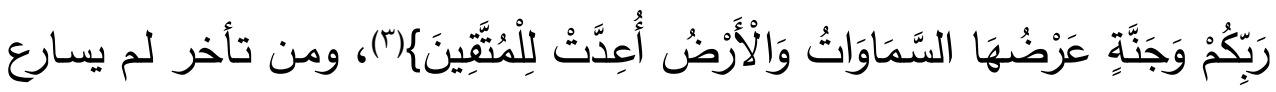
إلا أن يبيح التأخير نص فيوقف عنده.

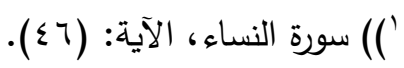
†') انظر : النبذة الكافيـة في أحكام أصسول الدين (النبذ في أصـول الفقه)، لابن حزم، المرجع

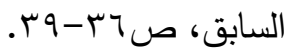

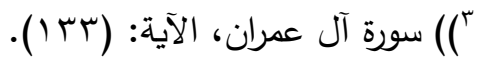


9- لا يجوز تأخير البيان عن وقت وجوب العمل بذلك الأمر ، إذ في

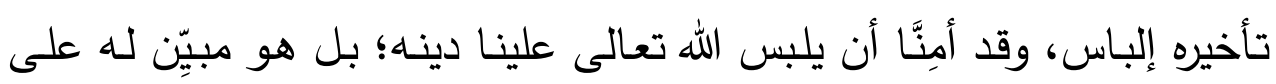
(') لسان من افترض عليه البيان • 1- والقرآن ينسخ القرآن، والسنة تنسخ القرآن أيضًا، قال الله تعالى: كوَما

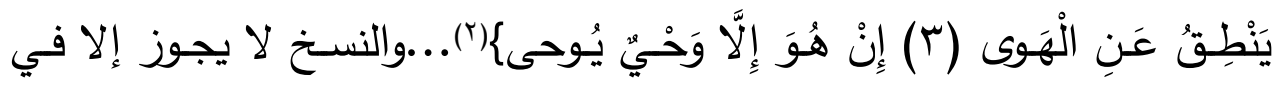

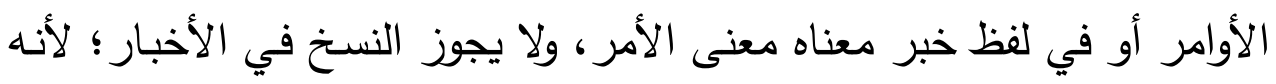
إن كان يكون كذبًا، وقد تنزه الله تعالى عن ذلك، وكذلك الرسل ملاه 1 - 1أوامر الله تعالى ورسوله صلى الله عليه وسلم كلها فرض، ونواهي

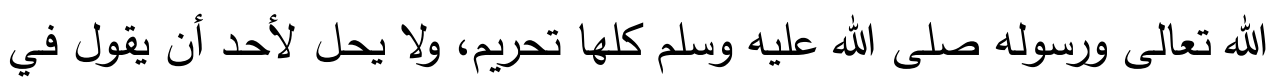

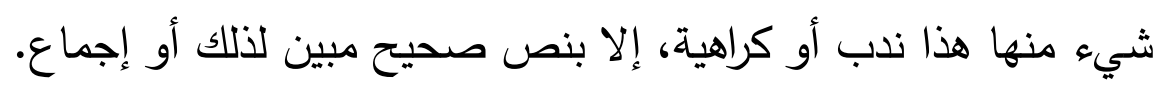
r ا الإباحة تتقسم أقسامًا ثلاثة: ندب يؤجر على فعله ولا يعصي بتركه

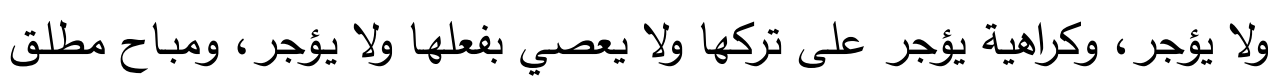

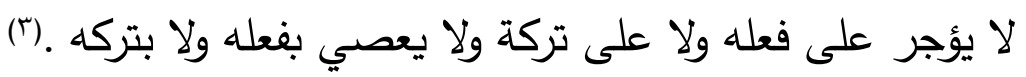

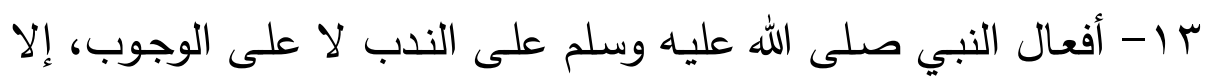
ما كان منها مبينا لأمر ، أو تنفيذا لحكم.

') انظر : النبذة الكافية في أحكام أصول الدين (النبذ في أصول الفقه)، لابن حزم، المرجع

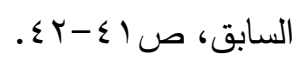

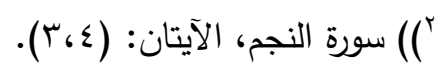
r) انظر : النبذة الكافيـة في أحكام أصول الدين (النبذ في أصسول الفقه)، لابن حزم، المرجع

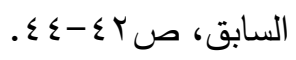


ع ا - لا حكم للخطـأ ولا للنسـيان ولا للإكـراه إلا حيـ أوجـب لـه الـص حكمًا، وإلا فلا يُبطل شيء من ذلك عملًا، ولا يُصلح عملًا. 1 - لا يصح عمل من أعمال الثريعة إلا بنية متصلة بأول الثروع فيه، لا يحول بين النية والدخول في العمل زمان أصلًا. 7 ا - كل مـا صـح بيقين؛ فـلا يبطل بالثك فيـه، سواء الطهارة والطـلاق والنكاح والملك والعتق والحياة والموت والإيمان والثرك والتمليك وانتقاله، وغير ذلك.

IV محدود المبدأ غير محدود الآخر، فما كان معلقا بوقت محدود الطرفين لم يجز

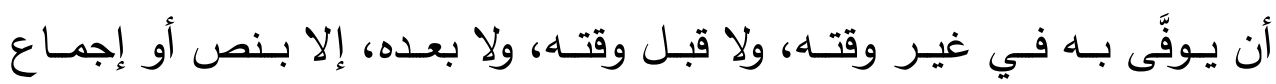
بالمجيء باه في غير وقته، فيوقف عنده، وإلا فلا. 1 ا - ما صح وجوبه غير مؤقت بنص أو إجماع؛ فلا يسقط إلا بنص أو إجماع، وما لم يجب؛ فلا يجب إلا بنص أو إجماع. 9 1 - لا يُلزم الخطأ إلا عاقلا بالغا قد بلغه الأمر.

• r- الاستثناء جائز من جنس الثيء ومن غير جنسه، وكذلك الاستثناء من جملة يبقى منها أصلها؛ لأن الاستثناء معروف في لغة العرب، فلا يجوز المنع منه بغير نص ولا إجماع. ا Y- كل من روى عن صاحب ولم يسمه؛ فإن كان ذلك الراوي ممن لا يجهل صحة قول مدعي الصحبة من بطلانهـ فهو خبر مسند تقوم بـ حجة؛ لأن جميع الصحابة عدول، وإن كان الراوي ممن يمكن أن يجهل صحة قول 
مدعي الصحبة؛ فهو حديث مرسل، إذ لا يؤمن فاسق من الناس أن يدعي لمن لا يعرف الصحابة أنه صاحب وهو كاذب في ذلك، فأمسا إذا روى الراوي الثقة عن بعض أزواج النبي صلى الله عليه وسلم خبرًا، فهو حجة؛ لأنهن لا يمكن أن يخفين عن أحد من أهل التمييز في ذلك الوقت. r r- إذا روى الصاحب حديثا عن النبي صلى الله عليه وسلم، وروي عن ذلك الصـاحب أنـه فعل خلافًا لمـا روى؛ فالفرض الحق أخذ روايته وترك مـا

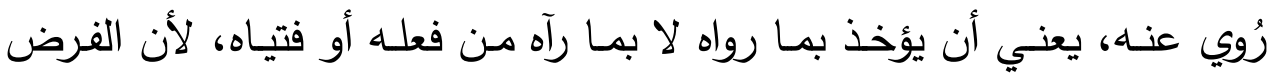
(') علينا قبول نقله عن النبي صلى الله عليه وسلم، لا قبول اختياره بr - والمتشـابه من القرآن هو الحروف المقطعة والأقسام فقط إذ لا نص في شرحها ولا إجماع وليس فيما عدا ذلك متشابه على الإطلاق. ع ז- ولا يلزم الفرض إلا من أطاقه إلا أن يأتي نص أو إجماع بأنه يلزمـه ويؤديه عنه غيره فيجزيـه.

هب - وكل مـا صـح أنـه كان في عصـر النبي صلى الله عليه وسـلم فـلا حجة فيه حتى ندري أنه صلى الله عليه وسلم عرفه ولم ينكره لأنه لا حجة في سواه، والحجة لا تكون إلا في نص قرآن أو نص خبر مسند ثابت عن رسول الله صـلى الله عليـه وسـلم أو في شـيء رآه عليـه السـلام فأقره؛ لأنـه صـلى الله عليه وسلم مفترض عليه البيان.

דr - والحق من الأقوال كلها فواحد وسـائرها خطأ، وإذا كان في المسألة

أقوال متعددة محصورة، فبطلت كلها إلا واحدًا، فذلك الواحد هو الحق بيقين؛

')) انظر : النبذة الكافيـة في أحكام أصول الدين (النبذ في أصـول الفقه)، لابن حزم، المرجع السابق، صـ ؟ - § 0. 
لأنه لم يبق غيره، والحق لا يخرج عن أقوال جميع الأمة، لما ذكرنا من عصمة

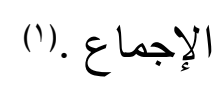

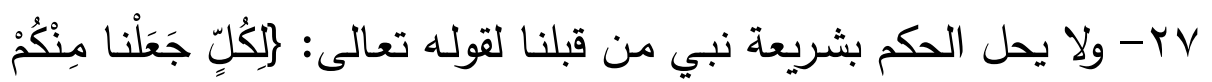

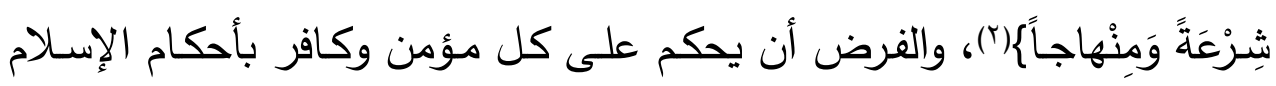

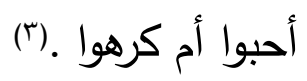

^ץ- لا يحل لأحد الحكم بالرأي قال الله تعالى: رما فَرَّطنا فِي الْكِتابِ مِنْ

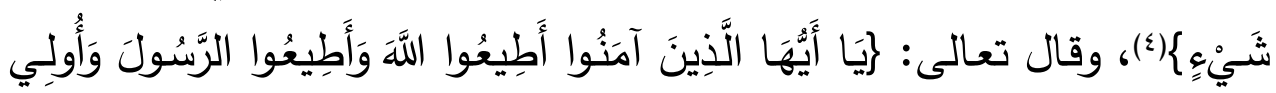

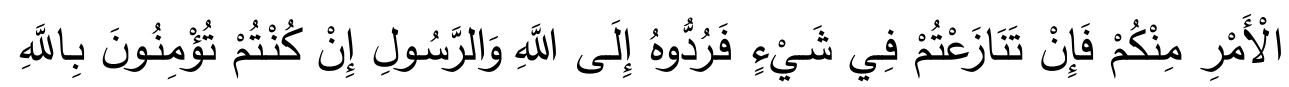

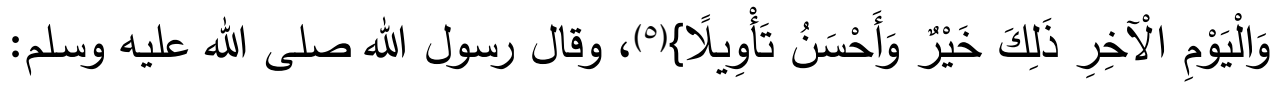

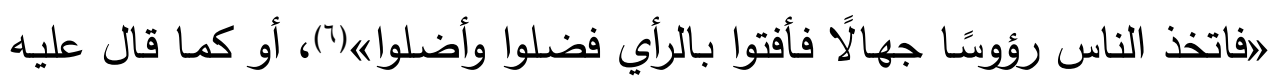
السلام، ولا يحل الحكم بالقياس في الدين والقول به باطل مقطوع على بلى بطلانه عند الله تعالى برهان ذلك ما ذكرناه آنفا في إبطال الرأي.

') (انظر : النبذة الكافية في أحكام أصول الدين (النبذ في أصول الفقه)، لابن حزم، المرجع

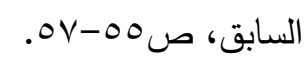

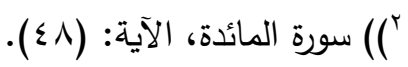

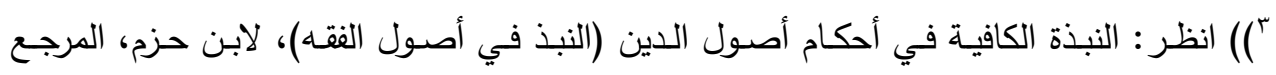

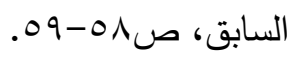

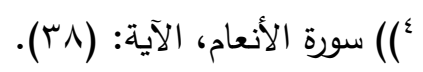

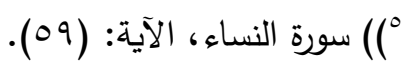

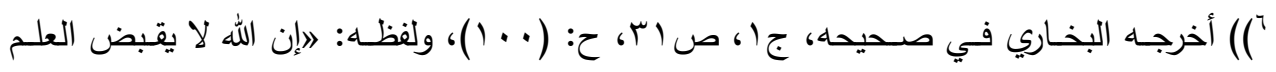

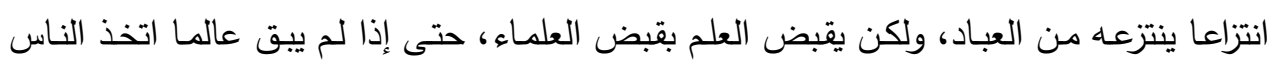
رؤوسا جهالا، فسئلوا فأفتوا بغير علم، فضلوا وأضلواهن. 
q ب- والثريعة كلها إما فرض وهو الواجب واللازم، وإما حرام وهو المنهي

عنه والمحظور ، وإما حلال، وإما تطوع مندوب إليه، وإما مباح مطلق.

• ب- وإذا نص النبي صلى الله عليه وسلم على أن حكم كذا في أمر كذا، لم يجز أن يتعدى بذلك الحكم ذلك الثيء المحكوم فيه، فمن خالف ذلك فقد تعدى حدود الله.(')

اس- وإذا أمر الله تعالى رسوله صلى الله عليه وسلم بأمر فهو لازم لكل مسلم، إلا إذا صح أن يأتي نص أو إجماع متيقن بتخصيصه بذلك. rr- والتقليد حرام ولا يحل لأحد أن يأخذ بقول أحد بـلا برهان.... والعامي والعالم في ذلك سواء وعلى كل أحد حظه الذي يقدر عليه من الاجتهاد، وإنما افترض الله تعالى علينا اتباع رسوله محمد صلى الله عليه وسلم فمن اتبعه وأقر بـه مصـدقا بقلبـه ولسـانه فقد وفق وهـو مـؤهن حقـا باسـتـلال كـان أو بغيـر

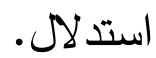

سب- ومن لم تقم عليه الحجة فمعذور وأما من قامت عليه الحجة فلا عذر آلمر لله، ومن عرف مسألة واحدة فصاعدا على حقها من القرآن والسنة جاز لله أن يفتي بها، ومن علم جمهور الدين كذلك، ومن خفي عليه ولو مسألة تحل له الفتيا فيما علم، ولا يحل الفتيا فيما لم يعلم، ولو لم يفت إلا من أحاط بالدين

كله علما لما حل لأحد أن يفتي بعد رسول الله صلى الله عليه وسلم. (r)

')) انظر : النبذة الكافية في أحكام أصول الدين (النبذ في أصـول الفقه)، لابن حزم، المرجع

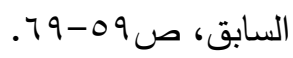

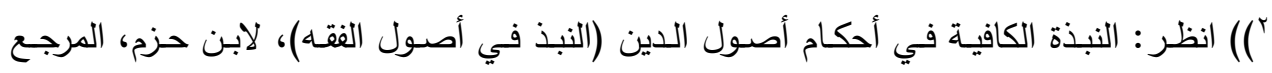

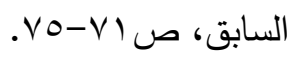




\section{وهذه الأصول يمكن اختصارها فيما يلي:}

1- القرآن الكريم: هو الأصل الأول للشريعة كلها، وما من أصل إلا يرجع إليه، يقول ابن حزم: "قال علي: ولما تبين بالبراهين والمعجزات أن القرآن هو عهد الله إلينا والذي ألزمنا الإقرار به والعمل بما فيه وصح بنقل الكافة الذي لا لأل مجال للشك فيه أن هذا القرآن هو المكتوب في المصاحف المشهورة في الآفاق كلها وجب الانقياد لما فيه فكان هو الأصل المرجوع إليه" . (1) r- السنة: وهي إمـا بنقل جماعـة عنـه صلى الله عليه وسلم، وإمـا برواية الثقات واحدا عن واحد، وأما الموقوف والمرسل فلا يحتج بهما عند ابن حزم، حيث يقول: "الموقوف والمرسل لا تقوم بهما حجة، وكذلك ما لم يروه إلا من لا يوثق بدينه وبحفظه". (؟) r- الإجماع: وهو مصدر تشريعي مهم عند ابن حزم، حيث يقول: "وأما الإجمـاع الذي تقوم بـه الحجـة في الثـريعة فهو مـا اتفق أن جميع الصـحابة رضي الله عنهم قالوه ودانوا بـه عن نبيهم صلى الله عليه وسلم وليس الإجماع في الدين شيئا غير هذا".(r) ع- عدم الأخذ بالقياس ولا بالرأي: يقول ابن حزم: "ولا يحل القول بالقياس في الدين ولا بالرأي؛ لأن أمر الله تعالى عند التتازع بالرد إلى كتابه وإلى رسوله ')) أبو محمد علي بن أحمد بن سعيد بن حزم الأنلسي القرطبي الظاهري (المتوفى: 107 کهـ)،

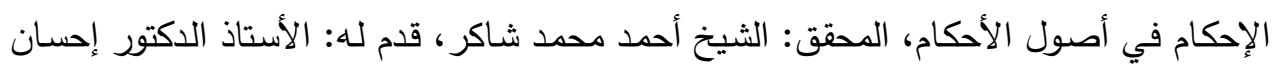

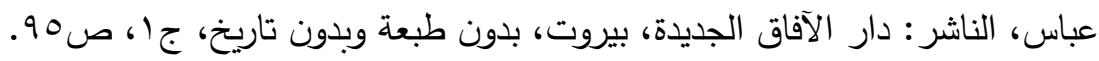

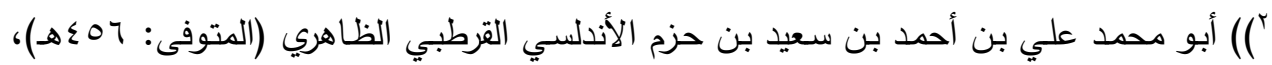

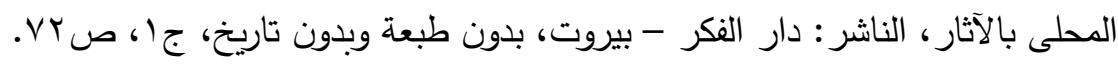

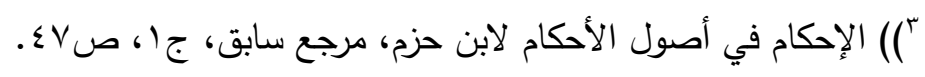


صلى الله عليه وسلم قد صسح، فمن رد إلى قياس وإلى تعليل يدعيه أو إلى رأي؛ فقد خـالف أمر الله تعـالى المعلق بالإيمان، ورد إلى غير فئ من أمـر الله تعالى بالرد إليه، وفي هذا ما فيه". (1)

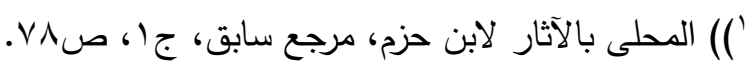




\section{المبحث الثاني}

انفرادات ابن حزم في باب الطلاق

سبق وبينا أن لابن حزم فقهه الخاص الذي يعتمد على ظواهر النصوص في الأساس مع الإجماع المعتبر عنده، مع منع التقليد وإبطال الرأي والقياس، لهن ولذا فقد كان لله آراء فقهية ليست في فقه الأئمسة الأربعة ولا غيرها، انفرد بها وحده تبعاً لأصول مذهبه الغريد. ومن هذه الآراء التي يخالف بها الأربعة: - أنه يرى أن تصرف المريض مرض الموت تبرعاً أو غير تبرع كتصرف الصحيح، لا فرق بينهما. - ويرى أن تصدق المرأة من مال زوجها جائز . - ويرى أيضاً أنه يجوز للقاضي أن يعدل في وصية أوصى بها شخص إذا كان فيها حيف أو إثم. - وأنه يجوز للقاضدي أن ينفذ وصية بقدر معلوم لبعض أقارب المتوفى الضعاف الذين لا يرثون، وقد اعتمد على ذلك قانون الوصية في تقريره الوصية الواجبة.

- وابن حزم يخالف جمهور الفقهاء في مسألة مهمة من مسائل

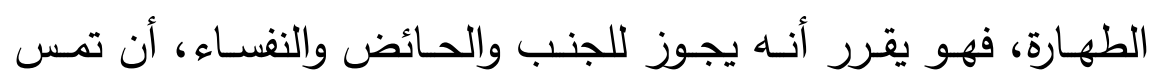
المصحف، وتقرأ القرآن الكريم، ويجوز بالأولى ذلك لغير المتوضـئ، 
ويحـاول أن يـدحض كـل الأدلـة التـي يسـوقها الفقهاء لإثبـات تحـريم

ذلك. (')

خلاصـة القول إن ابن حزم لون آخر من الفقه، ولـه انفراداته التي خالف

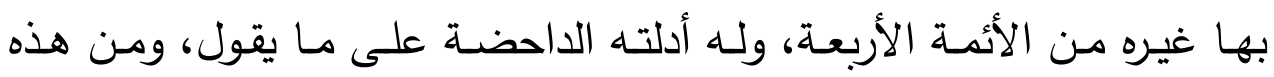
الانفرادات ما جاء بها في باب الطلاق، وقد تتبعها البحث في بحثه هذا، فوجد أن هذه الانفرادات تتركز في ستة مسـائل فقهية، خالف فيها ابن حزم الأئمـة

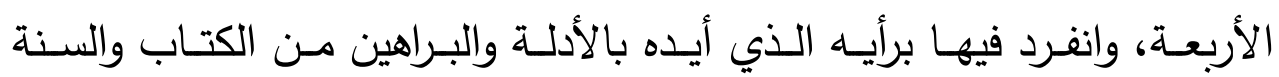

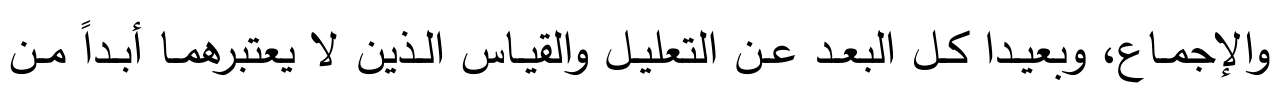
مصادر التشريع الإسلامي.

')() انظر : ابن حزم للإمام محمد أبو زهرة، مرجع سابق، صسYV. 


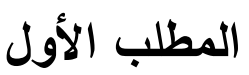

\section{قوله إنّ الإثهاد شرط لصحة الطلاق وصحة الرجعة}

ذهب الحنفية إلى عدم وجوب الإثهاد في الطلاق وكذا في الرجعة، قال

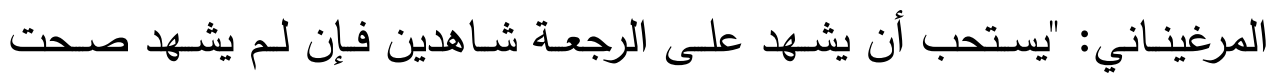

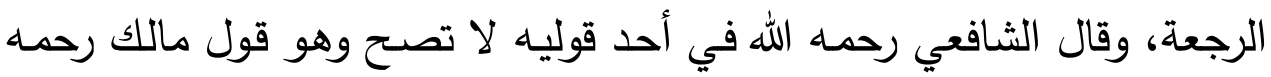

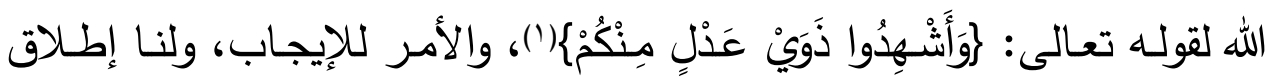

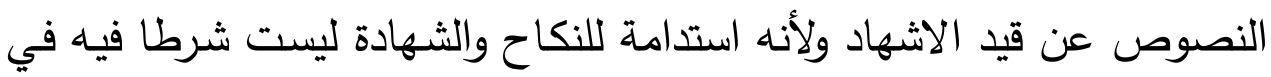

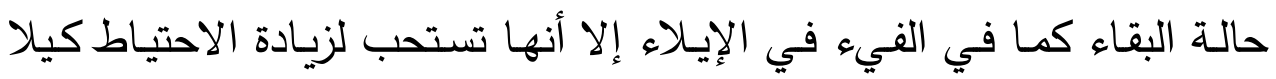

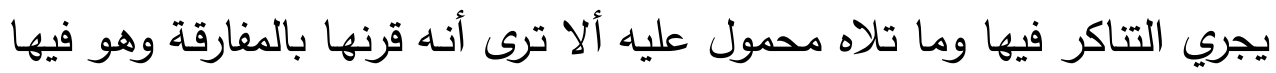

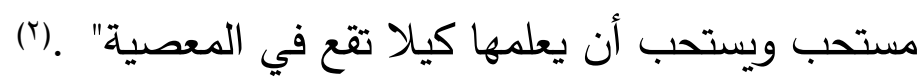
وعند المالكية أن "من طلق فليُشهـ على طلاقه وعلى رجعته، قال مالك

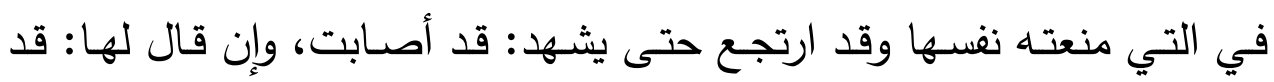

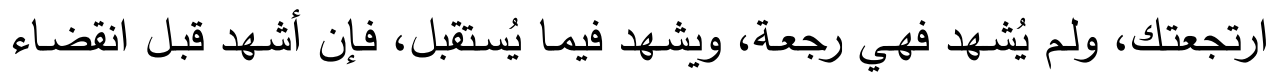

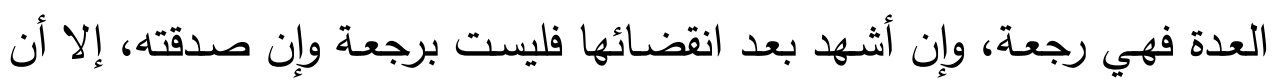

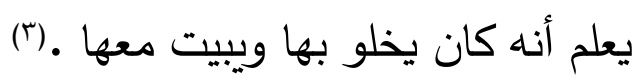

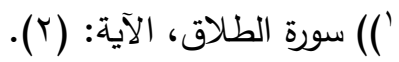

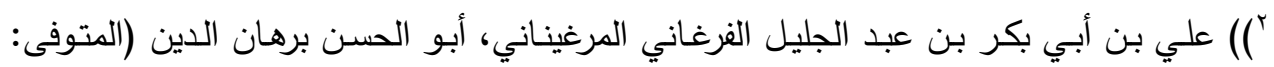

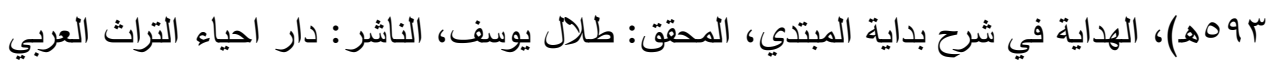

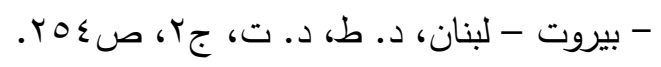

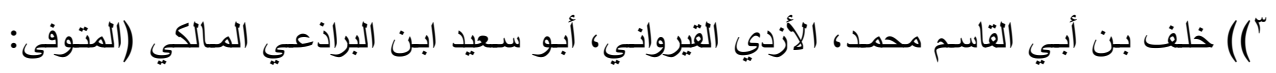
 
وندب لمن راجعها الإشهاد على الرجعة لدفع إيهام الزنا، ولا يجب خلافا

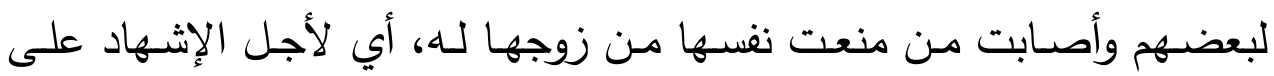
مراجعتها، وذلك دليل على كمال رشدها .(1) وقال الشـافعي رحمـه الله: ينبغي لمن راجع أن يشهـ شاهدين عدلين على الرجعة لما أمر الله تعالى به من الشهادة لئلا يموت قبل أن يقر بذلك أو يموت قبل تعلم الرجعة بعد انقضاء عدتها فلا يتوارثان إن لم تعلم الرجعة في العدة ولئلا يتجاحدا أو يصيبها فتتزل منه إصابة غير زوجة ولو تصـادقا أنه راجعها ولم يشهد فالرجعة ثابتة عليها لأن الرجعة إليه دونها وكذلك لو ثبت عليها ما كانت في العدة إذا أثها على أنـه قال قد راجعتها فإذا مضت العدة فقال قد (r). راجعتها وأنكرت فالقول قولها وعليه البينة أنه قال قد راجعتها في العدة وليس الإشهاد بواجب عند الحنابلة، قال البهوتي: "ويسن الإشهاد على الرجعة وليس شرطا فيها لأنها لا تفتقر إلى قبول فلم تفتقر إلى شهادة وجملة ذلك أن الرجعة لا تقتقر إلى ولي ولا صداق ولا رضى المرأة ولا علمها وهي أي

الثيخ، الناشر : دار البحوث للاراسات الإسلامية وإحياء التراث، دبي، الطبعة: الأولى، بr؟؛ اهـ -

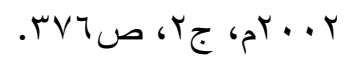

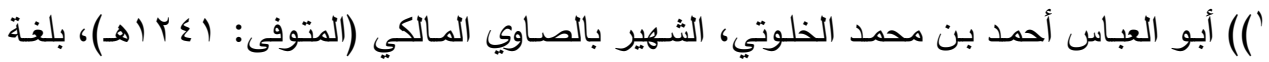

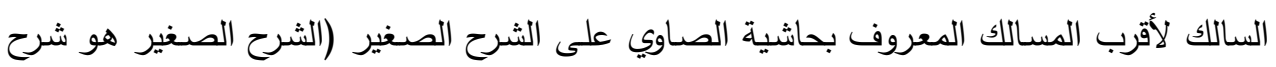

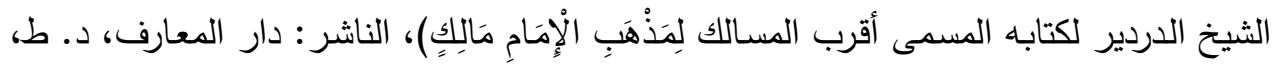

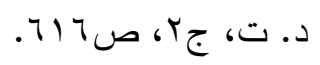

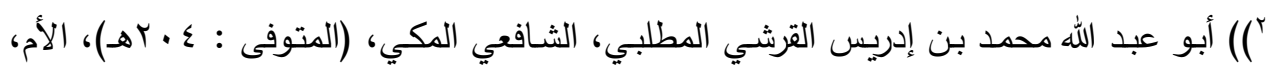

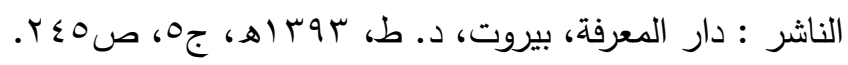


الرجعية زوجة يملك منها ما يملكه ممن لم يطلقها ولها ما للزوجات من نفقة وكسوة ومسكن وعليها حكم الزوجات من لزوم مسكن ونحوه لكن لا قسم لها". (') ويرى ابن حزم وجوب الإشهاد، فيقول: "فإن وطئها لم يكن بذلك مراجعا لها حتى يلفظ بالرجعة ويشهد، ويعلها بذلك قبل تمام عدتها، فإن راجع ولم

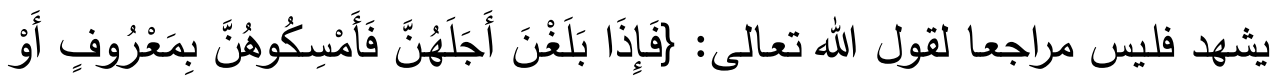

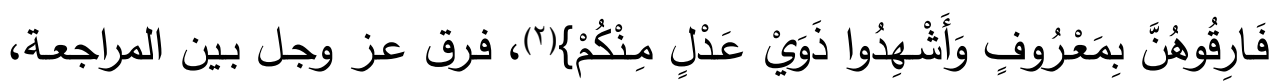
والطلاق والإشهاد، فلا يجوز إفراد بعض ذلك عن بعض، وكان من طلق ولم يشهح ذوي عدل، أو راجع ولم يشهح ذوي عدل، متعديا لحدود الله تعالى. وقال رسول الله صلى الله عليه وسلم: اهن عمل عملا ليس عليه أمرنا فهو رده.(؟)

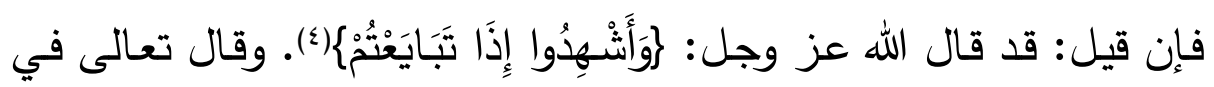

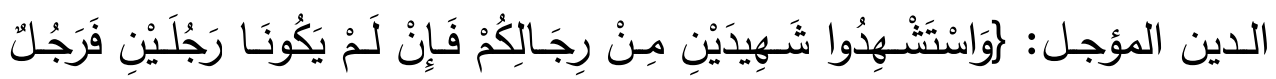

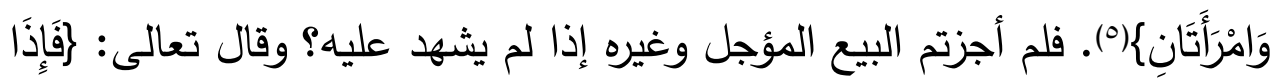

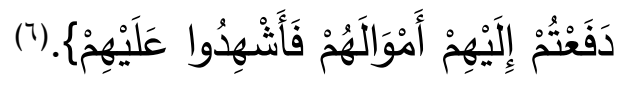

')) منصـور بـن يـونس بـن صـلاح الـين ابـن حسـن بـن إدريس البهـوتى الحنبلى (المتوفى:

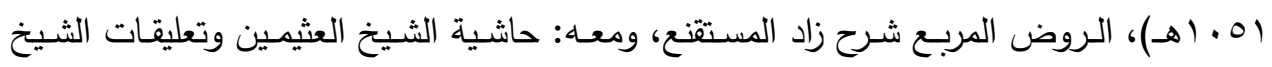
السعدي، خرج أحاديثه: عبد القدوس محمد نذير ، الناشر : دار المؤيد - مؤسسة الرسالة، د. ط، د. د.

$$
\begin{aligned}
& \text { ت، ج) ص40Nv-0NT. }
\end{aligned}
$$

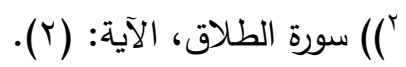

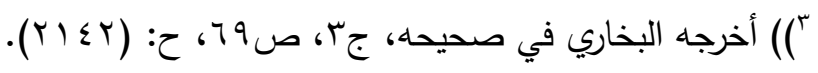

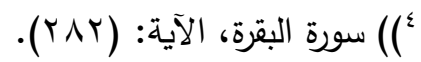

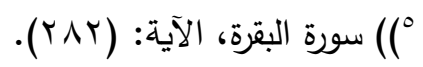

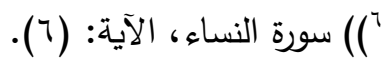


فلم أجزتم الدفع إلى اليتيم مالـه إذا بلـخ مميزا دون إثـهاد؟ قلنا: لم نجز

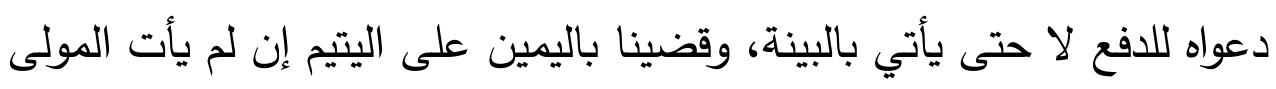

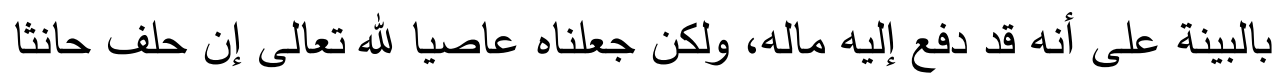

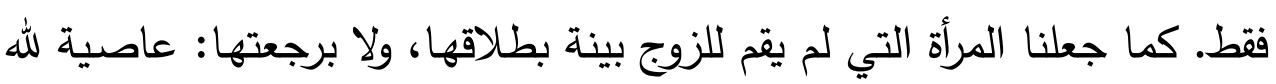
عز وجل إن حلفت حانثة، عالمة بأنه قد طلقها أو راجعها. (') فالجمهور لا يرون الإثـهاد واجبـا في الطـلاق أو في الرجعـة وإنما هو مستحب، بينما ابن حزم يرى وجوبه في الحالتين.

')( انظر : المحلى بالآثار لابن حزم، مرجع سابق، ج· (1، صلا (1) . 


\section{المطاب الثاني}

\section{إنكاره الإجماع بوقوع الطلاق في الحيض (الطلاق البدعي)}

الطلاق البدعي: هو الطلاق المخالف للشرع، كأن يطلقها في حيض أو نفاس، أو في طهر جامعها فيه ولم يتبين حملها، فهذا الطلاق محرم، وفاعله آثم، أو يطلقها ثلاثا بكلمـة واحدة فيقول: أنت طـالق ثلاثا، أو بـالثلاث، أو يطلقها ثلاثا متفرقات في مجلس واحد فيقول: أنت طالق، طالق، طالق، وهذا الطلاق محرم؛ لأنه في غير العدة المشروعة للطلاق، ومن طلق هذا الطلاق

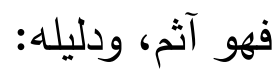

1 - عن ابن عمر رضي الله عنهما أنه طلق امرأته وهي حائض، فذكر ذلك عمر للنبي صلى الله عليه وسلم، فقال: اهره فليراجعها، ثم ليطلقها طاهرا

$$
\text { (1). أو حاملاني }
$$

r - وعن ابن عمر رضي الله عنهما أنه طلق امرأته وهي حائض، فسأل عمر عن ذلك رسـول الله صـلى الله عليـه وسـلم؛ فقـال: الهـره فليراجعها حتى تطهر، ثم تحيض حيضة أخرى، ثم تطهر، ثم يطلق بعد، أو يمسكه .(؟) فالطلاق البدعي منهي عنه محرم، وقد اختُلف فيه هل يقع ويعتد به أم لا يقع؟ فقال الجمهور : يقع، مستدلين بقوله في هذا الحديث، وفي رواية أخرى للبخاري: 》حُسبَبت عليَّ بتطليقة)(َّ)، وهو بضم الحاء المهملة ومبني للمجهول من الحسـاب، والمراد جعلها واحدة من الثلاث التطليقات التي يملكها الزوج،

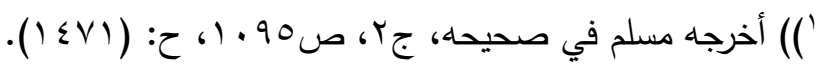

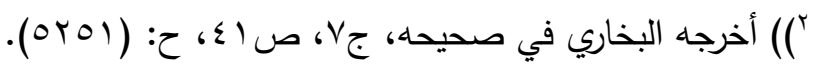

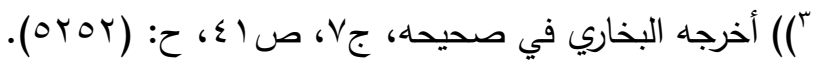


ولكنه لم يصرح بالفاعل، هنا فإن كان الفاعل ابن عمر فلا حجة فيه، وإن كان النبي صلى الله عليه وسلم فهو الحجة، إلا أنه قد صرح بالفاعل في غير هذه الرواية، كما في مسند ابن وهب بلفظ: وزاد ابن أبي ذئب في الحديث عن النبي صلى الله عليه وسلم: اوهي واحدة|ه، وأخرجه الدارقطني من حديث ابن أبي ذئب وابن إسـحاق جميعا عن نـافع عن ابن عمر عن النبي صـلى الله عليه وسلم قال: 》هي واحدة《.

وقد ورد أن الحاسب لها هو النبي صلى الله عليه وسلم من طرق يقوي بعضها بعضـا. وفي روايـة لمسلم قال ابن عمر - أي لما سأله سـائل - أمـا أنت طلقتها واحدة أو اثنتين؟: "فإن رسول الله صلى الله عليه وسلم أمرني أن أراجعها ثم أمسكها حتى تحيض حيضة أخرى ثم أمهلها حتى تطهر ثم أطلقها قبل أن أمسها، وأما أنت طلقتها ثلاثا فقد عصيت ربك فيما أمرك به من طلاق امرأتك"(')، دل على تحريم الطلاق في الحيض. وقد يـدل قولـه: "أمرني أن أراجعها" على وقوع الطـلاق، إذ الرجعـة فرع

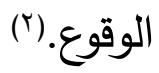

والطلاق البدعي يقع عند الأحنـاف، قال الموصلي: "والبدعـة أن يطلقها ثلاثاً أو ثتين بكلمة واحدة أو في طهر لا رجعة فيه، أو يطلقها وهي حائض فيقع ويكون عاصياً، وطلاق غير المدخول بها حالة الحيض ليس ببدعي، وإذا

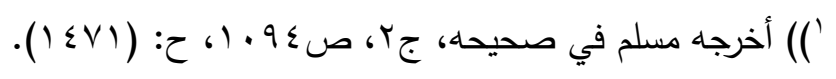

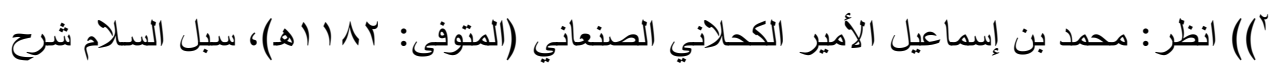

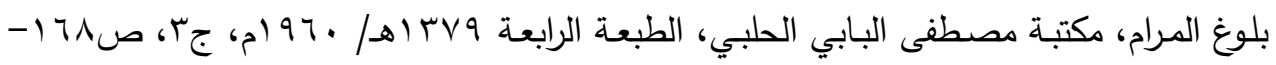


طلق امرأته حالة الحيض فعليه أن يراجعها، فإذا طهرت فإن شاء طلقها وإن

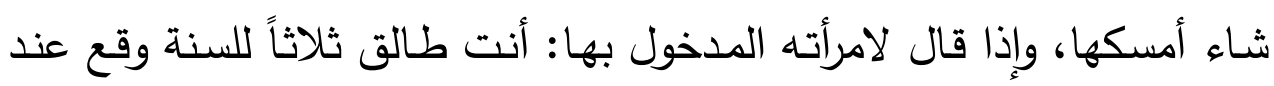
(') . كل طهر تطليقة، وإن نوى وقوعهن الساعة وقعن

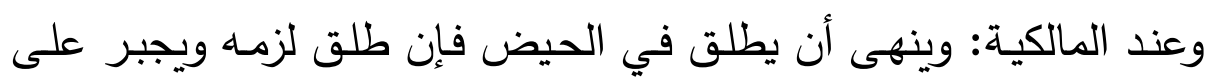
الرجعة ما لم تتضض العدة والتي لم يدخل بها يطلقها متى شاء والواحدة تبينها.

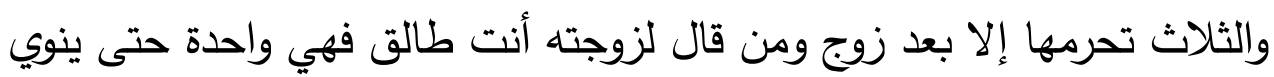

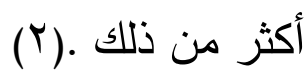
وكذا عند الثافعية: "من طلق طلاقا بدعيا ولم يستوف عدد الطلاق، سن

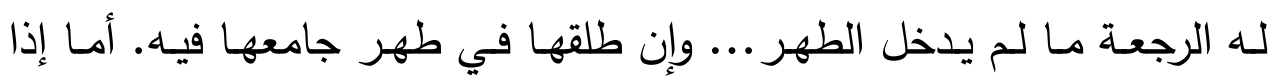

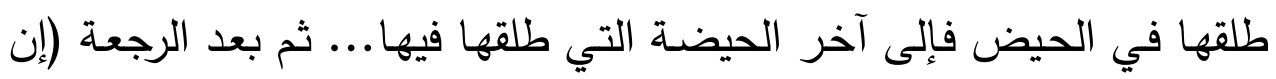

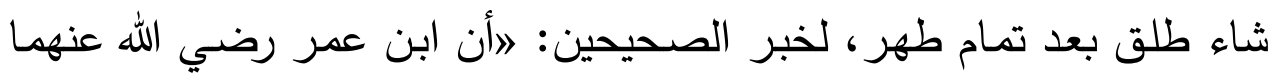
طلق زوجته وهي حائض فذكر ذلك عمر للنبي صلى الله عليه وسلم فقال : مره

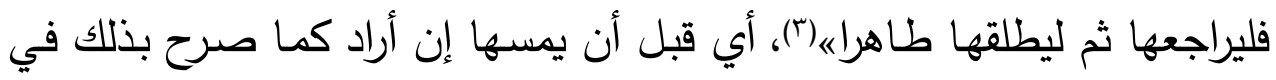

(๕). "بعض رواياتهما

')) عبد الله بن محمود بن مودود الموصلي البلدحي، مجد الدين أبو الفضل الحنفي (المتوفى: بآهـه)،

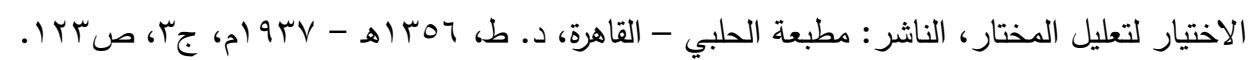

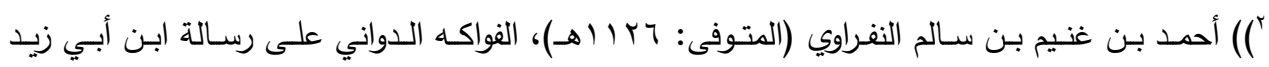

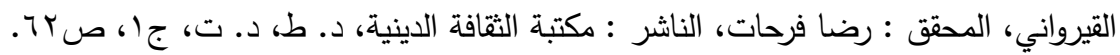

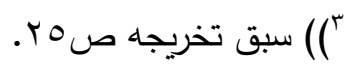
צ)) شمس الدين، محمد بن أحمد الخطيب الثربيني الثافعي (المتوفى: وVVهـ)، مغني المحتاج

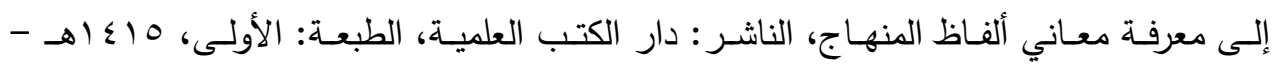

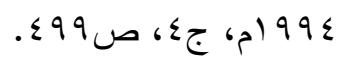


كما يقع عند الحنابلة، قال المقدسي: "وإن قال لها أنت طالق للبدعة وهي

حائض أو في طهر أصابها فيه طلقت" . (1)

ويقول ابن حزم: روينا من طريق عبد الرزاق عن وهب بن نافع أن عكرمة

أخبره: أنه سهع ابن عباس يقول: الطلاق على أربعة أوجها: وجهان حلال،

ووجهان حـرام، فأمسا الحـلال فأن يطلقها مـن غير جمـاع أو حساملا مستبينا حملها، وأما الحرام فأن يطلقها حائضا أو حين يجامعها لا يدري أيشتمل الرحم

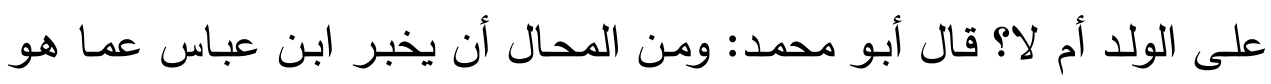
جائز بأنـه حرام... فكيف يستجيزون الحكم بتجويز البدعة التي يقرون أنها بدعة وضلالة؟ أليس بحكم المشاهدة مجيز البدعة مخالفا لإجماع القائلين بأنها

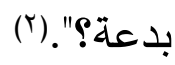

')) عبد الرحمن بن إبراهيم بن أحمد، أبو محمد بهاء الدين المقدسي (المتوفى: ـ ك7هـ)، العدة

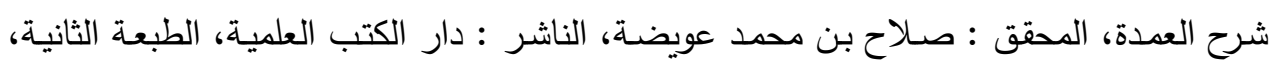

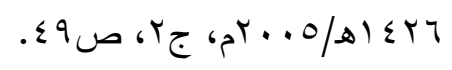

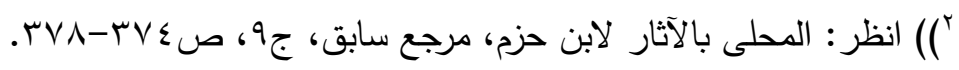




\section{المطلب الثالث}

\section{قوله: إنَّ إعلام الزوجة بالطلاق شرط لصحة الطلاق}

$$
\text { وكذلك إعلام الزوجة بالرجعة شرط لصحة الرجعة }
$$

لا يشترط الحنفية الإعلام في الرجعة، ولا يشترط فيها رضـا المرأة؛ لأنها

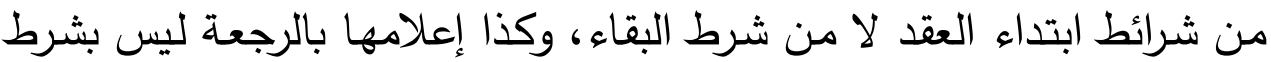

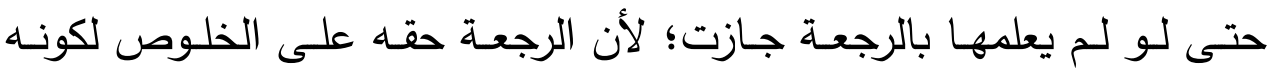

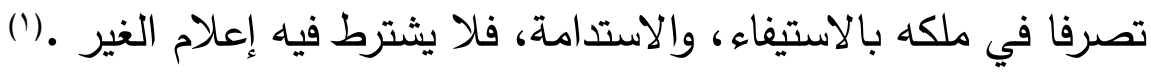
وعند المالكية: من طلق امرأته تطليقة يملك الرجعة فيها... وإن قال لها

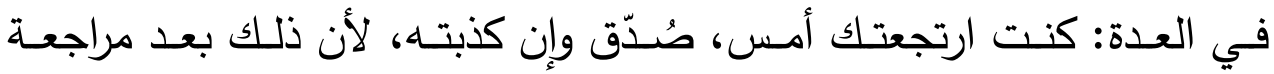
(ץ) الساعة (؟)

وعند الثافعية: "لا يشترط رضا الزوجة ولا رضا وليها ولا سيدها إذا كانت

$$
\text { (أمة، ويسن إعلام سيدها". (r) }
$$

وكذلك عند الحنابلة، وقد ذكر البهوتي قول ابن المنذر في وقوع الإجماع

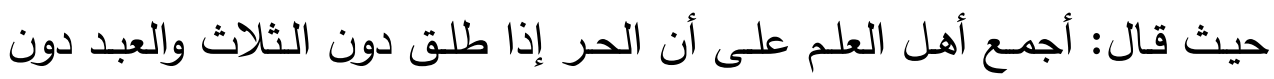

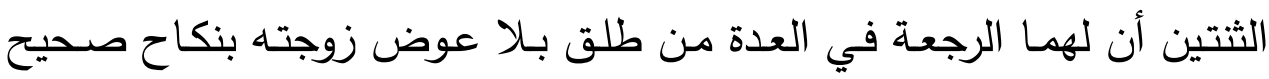

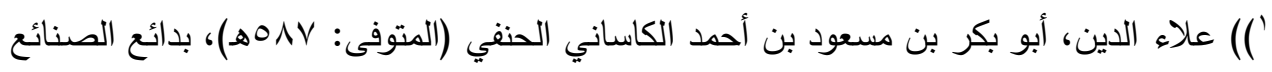

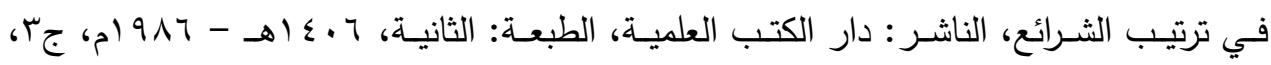

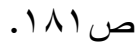

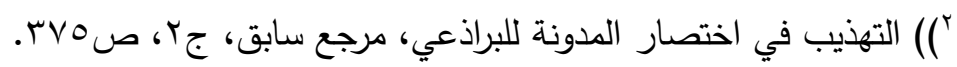

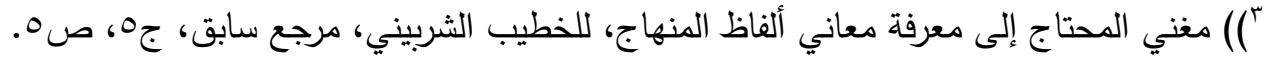


مدخولا بها أو مخلوا بها دون ما له من العدد بأن طلق حر دون ثلاث أو عبد دون ثنتين فله أي: للمطلق حرا كان أو عبدا أو لوليه إذا كان مجنونا رجعتها

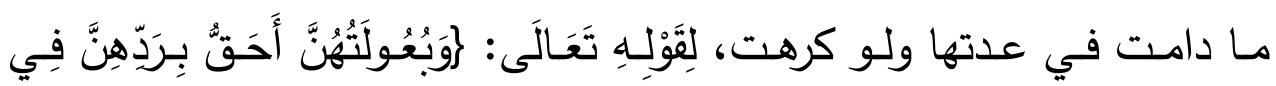

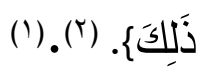

وذهب الظاهرية إلى وجوب إعلام الزوجة بالرجعة، فإن لم يعلهها لم يعتبر

مراجَعا، يقول ابن حزم: "وأما قولنا: إنه إن راجع ولم يشهد، أو أشهد ولم يعلمها حتى تتقضي عدتها - غائبا كان أو حاضرا - وقد طلقها وأعلمها وأشهد، فقد بانت منه، ولا رجعة له عليها إلا برضـاها بابتداء نكاح بولي، وإشهاد وصداق مبتدأ -سواء تزوجت أو لم تتزوج دخل بها الزوج الثاني أو لم يدخل- فإن أتاها الخبر -وهي بعد في العدة- فهي رجعة صحيحة.

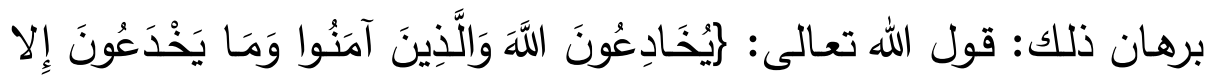

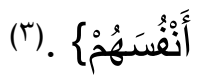

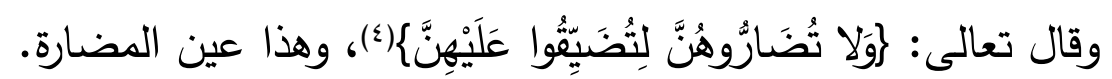

وقال رسول الله صلى الله عليه وسـلم: الهن عمل عملا ليس عليـه أمرنـا فهو رد《(')، فمضارته مردودة باطل.

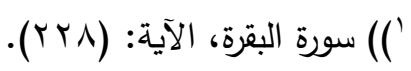

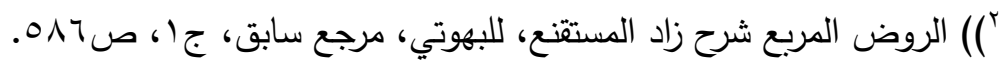

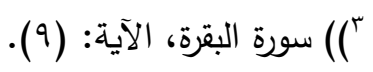

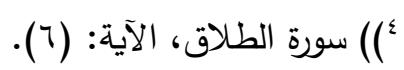

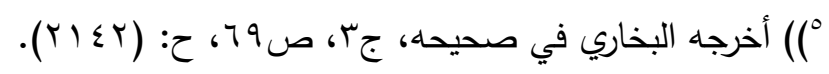


وأيضـا فإن الله تعالى سمى الرجعة إمساكا بمعروف، قال تعالى: رُفَاٍِاَ بَلَغْنَ

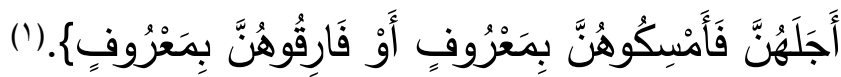

فالرجعـة هـي الإمسـاك، ولا تكـون بــص كـلام الله تعـالى إلا بمعـروف، والمعروف هو إعلامها، وإعـلام أهلها، إن كانت صـغيرة أو مجنونـة، فإن لـ يعلمها لم يمسك بمعروف، ولكن بمنكر، إذ منعها حقوق الزوجية: من النفقة، والكسـوة، والإسـكان، والقسـمة فهو إمسـالك فاسـ باطل مـا لم يشهـ بإعلامها فحينئذ يكون بمعروف.

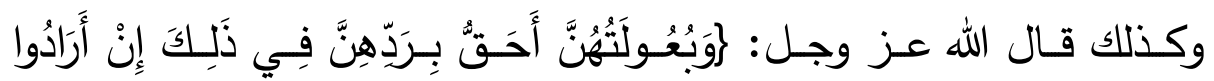

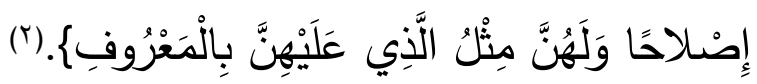

قـال أبـو محمد: إنمـا يكـون "البعـل" أحق بردهـا إن أراد إصـلاحا بـص

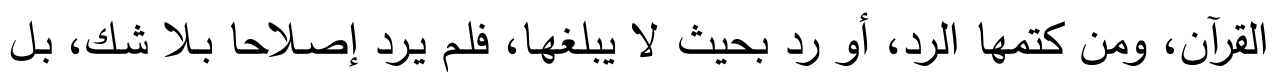
أراد الفساد، فليس ردا ولا رجعة أصلا".(r)

فالجمهور يستحبون إعلام الزوجة بالرجعة من غير إيجاب، وتصسح بغير إعلامها، وابن حزم يوجب إعلام الزوجة، ولا تصح الرجعة عنده بغير إعلامها.

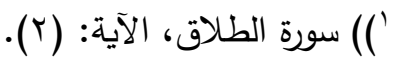

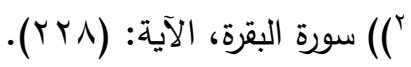

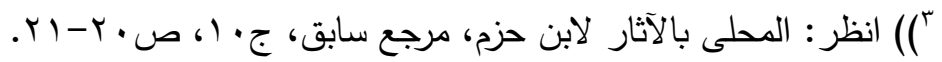




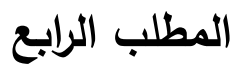

\section{قوله إن طلاق المريض البائن مرض الموت كطلاق الصحيح في أثره}

اتفق الفقهاء على أن المريض إذا طلق امرأتـه في مرض الموت فطلاقه نافذ كطلاق الصحيح، وتترتب عليه آثاره، فإذا مات من ذلك المرض، ورثته المطلقة ما دامت في العدة من طلاق رجعي، كما ترثه فيها في طلاقها في حـال الصـحة، أمـا إذا مـات في العـدة فقــ اختلف الفقهـاء في إرث الزوجـة المطلقة طلاقاً بائناً، فقال الجمهور : إنها ترثه.

واستدلوا بأن عثمان رضي الله عنه ورث تماضر بنت الأصبغ الكلبية من عبد الرحمن بن عوف وكان طلقها في مرضـه فبتها واشتهر ذلك في الصحابة فلم ينكر فكان إجماعا، ولم يثبت عن علي وعبد الرحمن خـاف هذا بل قد روى عروة أن عمر قال لعبد الرحمن إن مت فلا ورثتها منك قال قد علمت ذلك. (')

وأما ابن حزم فقد اعتبر أن طلاق المريض البائن كطلاق الصحيح في أنه لا يوجب الميراث، ولو مات في العدة فإن الطلاق عنده لا يوجب ميراثاً في العدة، يستوي في ذلك طلاق المريض وطلاق الصحيح، ويقول في ذلك رحمه الله: "وإقرار المريض في مرض موته، وفي مرض أفاق منه لوارث ولغير وارث نافذ من رأس المال كإقرار الصحيح، ولا فرق.

')) انظر : ابن قدامة المقدسي، عبد الرحمن بن محمد (المتوفى: بحآهـ)، الشرح الكبير على متن

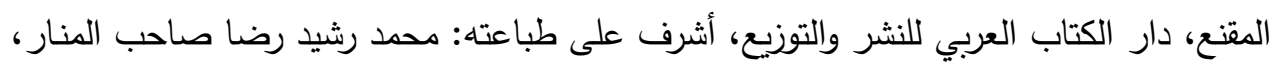

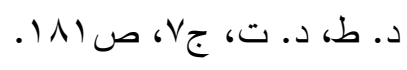


روينا من طريق عبد الرزاق، حدثنا بعض أصحابنا، عن الليث بن سعد، عن نافع مولى ابن عمر، عن ابن عمر قال: إذا أقر المريض في مرضه بدين لرجل فإنه جائز فعم ابن عمر ولم يخص.

ومن طريق ابن أبي شيبة، حدثنا ابن علية، عن ليث، عن طاووس، قال:

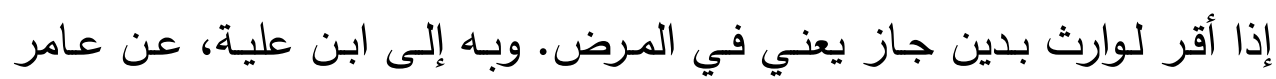
الأحول قال: سئل الحسن عنه؛ فقال: أحملها إياه، ولا أتحملها عنـه".(1) فطلاق المريض البائن عند ابن حزم كطلاق الصحيح في أنه لا يوجب الميراث، بينما هو عند الجمهور يختلف عن طلاق الصحيح ويوجب الميراث. 


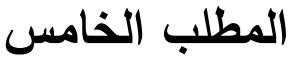

\section{قوله: إن الطلاق لا يقع إلا بألفاظه مع وجود النية}

يـرى الحنفيـة أن ركن الطـلاق هـ اللفظ الذي جعل دلالــة على معنى الطلاق لغـة، وهو التخليـة والإرسـال ورفع القيد في الصـريح، وقطع الوصـلة ونحوه في الكناية أو شرعا، وهو إزالة حل المحلية في النوعين أو ما يقوم مقام اللفظ أما اللفظ، فمثل أن يقول في الكناية: أنت بائن أو أبنتك، أو يقول في الصريح أنت طالق أو طلقتك، وما يجري هذا المجرى، ولهذا قالوا: إن من قال لامرأته أنت مطلقة مخففا يرجع إلى نيته لأن الإطلاق في العرف يستعمل في إثبات الانطلاق عن الحبس والقيد الحقيقي، فلا يحمل على القيد الحكمي إلا

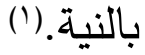

فالطلاق يقع بلفظه الصريح أو بالكناية، وكذا قال المالكية، فأركان الطلاق

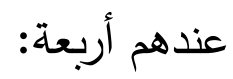

(أهل) والمراد به: موقعه من زوج أو نائبه أو وليه إن كان صغيرا، ولا يرد الفضولي لأن موقعه في الحقيقة هو الزوج بدليل أن العدة من يوم الإجازة لا الإيقاع.

(وقصد): أي قصد النطق باللفظ الصريح أو الكناية الظاهرة، ولو لم يقصد حل العصمة وقصد حلها في الكناية الخفية، واحترز بـه عن سبق اللسان في الأولين وعدم قصد حلها في الثالث. (ومحل): أي عصمة مملوكة تحقيقا أو تقديرا كما يأتي.

') انظر : بدائع الصنائع في ترتيب الشرائع، للكاساني، مرجع سابق، جّ، ص^91. 
(ولفظ): صـريح أو كنايـة ظـاهرة أو خفيـة، أي أو مـا يقوم مقامـه كالإشـارة والكتابة، لا بمجرد نية ولا بفعل إلا لعرف. والمراد بالركن: ما تحقق به الماهية

ولو لم يكن جزءا منها حقيقة.)

وأما عند الشافعية يشترط قصد لفظ الطلاق لمعناه، ولا يكفي قصد حروف الطـلاق مـن غيـر قصـــ معنـاه، فكيف يقـال إن الصـريح لا يحتـاج إلصى نيـة

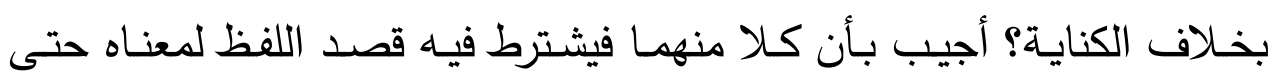
يخرج العجمي إذا لقن كلمـة الطـلاق وهو لا يعرف معناهـا فـلا يقـع طلاقهـ، والمـراد بالنيـة في الكنايـة أن يقصـد الإيقـاع، وليس بشـرط لمن عرف معنـاه

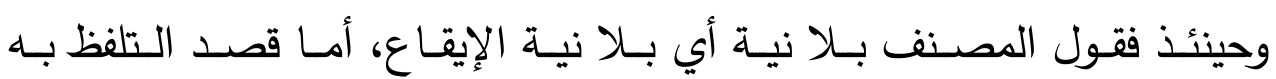
فيشترط.) (r)

وكذلك عند الحنابلة، يقول ابن قدامة: "وقولهم: إن الكناية بالنية كالصريح، قلنا: نعم، إلا أن الصريح ينقسم إلى ثلاث تحصل بها البينونة، وإلى ما دونها مما لا تحصل بـه البينونـة، فكذلك الكنايـة تنقسم كذلك، فمنهـا مـا يقوم مقام الصريح المحصل للبينونة، وهو هذه الظاهرة، ومنها ما يقوم مقام الواحدة، وهو ما عداها"، وهكذا لو نوى أنه ليس لي امرأة تخدمني، أو ترضيني، أو أني كمن

')) انظر : بلغة السالك لأقرب المسالك المعروف بحاشية الصاوي على الثرح الصغير ، للصاوي،

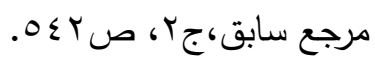

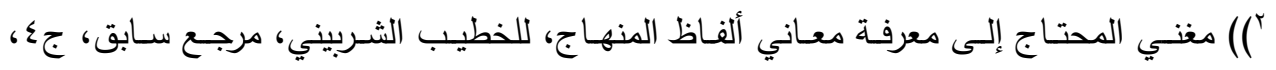

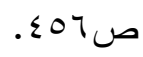


لا امرأة له، أو لم ينو شيئا لم تطلق؛ لعدم النية المشترطة في الكناية، وإن أراد

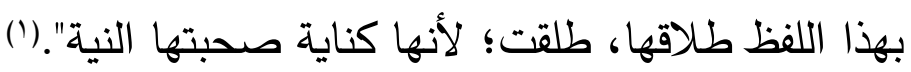

وعليه فقد اتفق جمهور الفقهاء على أن الزواج ينتهي بالطلاق بالعربية أو

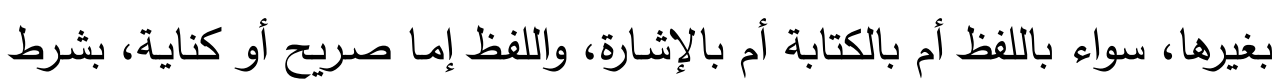

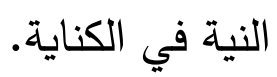

ويقول ابن حزم: "لا يقع طلاق إلا بلفظ من أحد ثلاثة ألفاظ: إما الطلاق، وإما

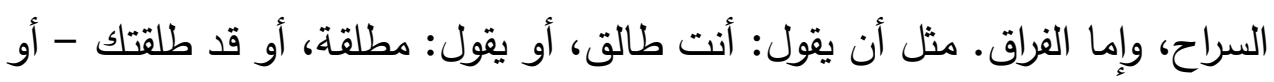

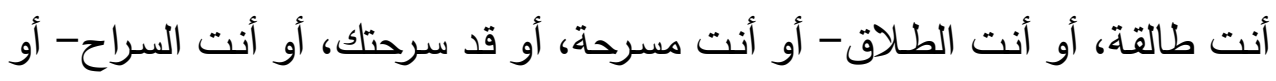

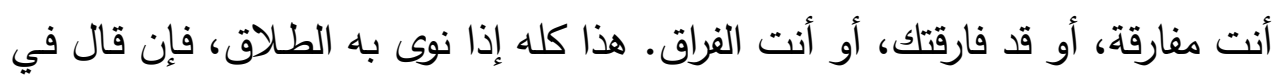

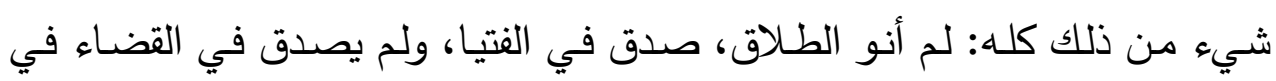
الطلاق، وما تصرف منه، وصدق في سائر ذلك في القضاء أيضا.

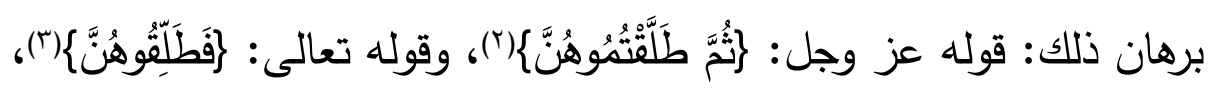

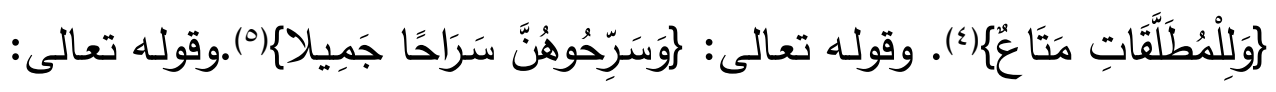

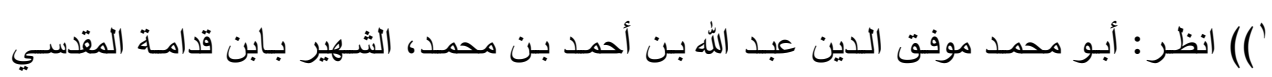

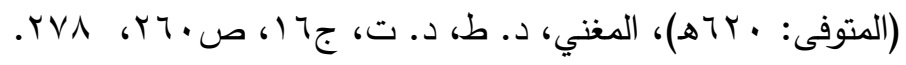

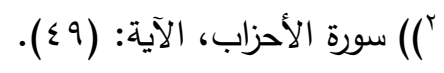

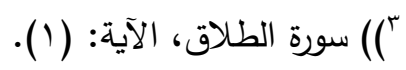

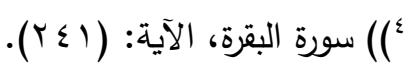

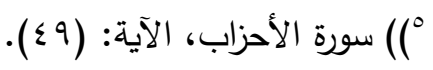




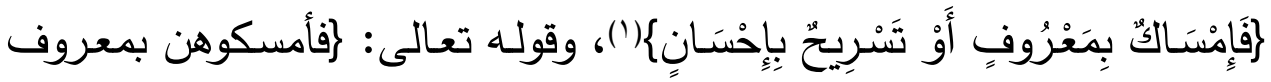

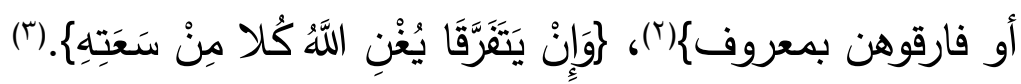
لم يذكر الله تعالى حل الزوج للزوجة إلا بهذه الألفاظ، فلا يجوز حل عقدة عقدت بكلمة الله عز وجل وسنة رسوله صلى الله عليه وسلم إلا بما نص الله

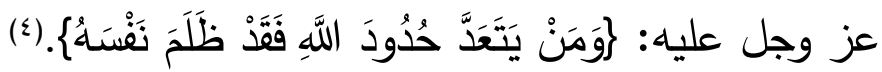
وأما قولنا: إن نوى مع ذلك الطلاق، فلقول رسول الله صلى الله عليه وآله وسلم:

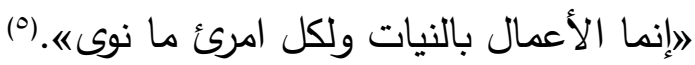

وأما تفريقنا بين ألفاظ الطلاق، فلم يوجب أن يراعى قوله فيها: لم أنو الطلاق

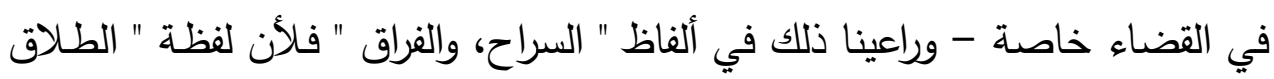
" وما تصرف منها لا يقع في اللغة التي خاطبنا الله عز وجل بها في أحكام الشريعة إلا على عقد الزواج فقط، لا معنى آخر ألبتة، فلا يجوز أن يصدق في دعواه في حكم قد ثبت بالبينة عليه وفي إسقاط حقوق وجبت يقينا للمرأة بالطلاق قبله".() فالجمهور يرون أن الطلاق يقع بصريح ألفاظه سواء اقترن بالنية أم لا، كما يقع بالكناية ولكن بشرط النية، وأما ابن حزم فيرى أن الطلاق لا يقع إلا بألفاظه ولا يقع بألفاظه إلا في وجود النية، ووافقه الثافعي في ألفاظ الطلاق فقط دون النية.

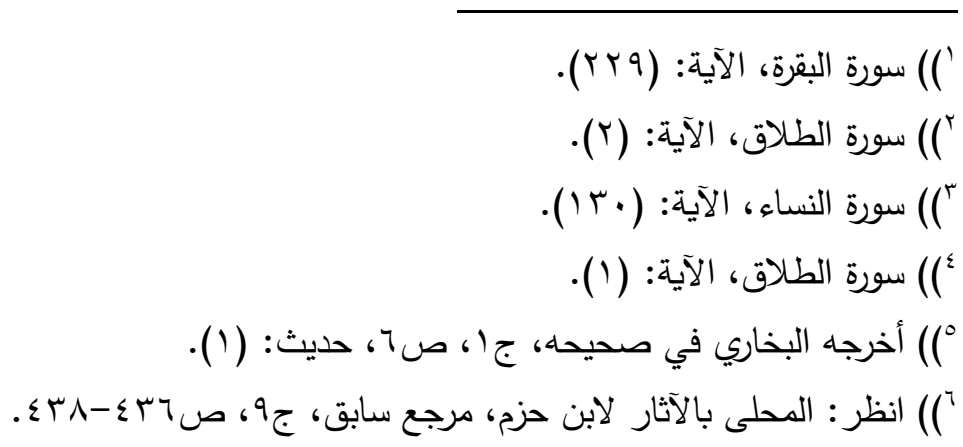




\section{المطلب السادس}

\section{قوله: إن الحلف بالطلاق والطلاق المعلق لا يقع بهما الطلاق}

الطلاق المعلق يقع عند الحنفية، وهو اليمين التي تعلق بها الطلاق عند وجود الشرط، وحكم هذه اليمين هو وقوع الطـلاق المعلق عند وجود الشرط، لأن اليمين بالطلاق هو تعليق الطلاق وبالثرط، ومعنى تعليقه بالثرط - وهو إيقاع الطلاق في زمان ما بعد الشرط - لا يعقل له معنى آخر ، فإذا وجد ركن الإيقاع مع شرائطه، لا بد من الوقوع عند الشرط.(') أما المالكية فالطلاق عندهم على نوعين: معجل ومعلق، فالمعجل ينفذ في الحين، وأمسا المعلق فهو الذي يعلق إلى زمن مستقبل أو وقوع صفة أو شرط وهو على سبعة أقسام: (الأول) أن يعلق بأمر يمكن أن يكون ويمكن ألا يكون كقوله إن دخلت الدار فأنت طالق وكذلك إن كلمت زيدا أو إن قدم فلان من سفره فهذا إن وقع الشرط وقع الطلاق وإلا لم يقع اتفاقا. (الثاني) أن يعلقه بأجل يبلغه العمر عادة أو بأمر لا بد أن يقع كقوله إن دخل الشهر أو إذا مـات فـلان فأنت طـالق فهذا يلزمـه الطـلاق في الحين ولا ينتظر به أجل الشرط خلافا لهما.

(الثالث) أن يعلقه بأمر يغلب وقوعه ويمكن ألا يقع كقوله أنت طالق إن حضت ففيه قولان قيل يعجل عليه الطلاق وقيل يؤخر إلى حصول شرطه وفاقا لهما.

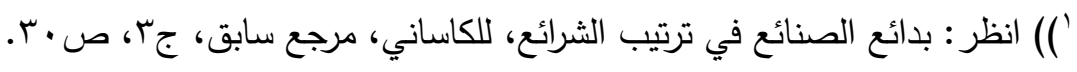


(الرابع) أن يعلقه بشرط يجهل وقوعه فإن كان لا سبيل إلى علمه طلقت

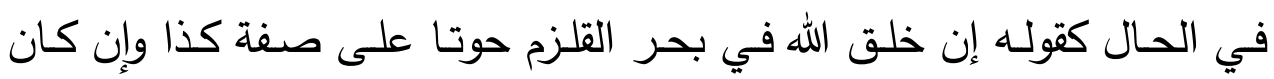
يوصل إلى علمه كقوله إن ولدت أنثى توقف الطلاق على وجوده. (الخامس) أن يعلقه بمشيئة الله تعالى فيقول أنت طالق إن شاء الله تعالى فيقع الطلاق ولا ينفع هذا الاستثناء خلافا لهما. (السادس) أن يعلقه بمشيئة إنسان كقوله أنت طالق إن شاء زيد فيتوقف

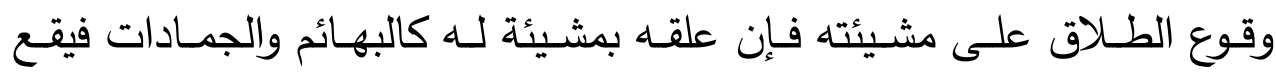
الطلاق في الحين لأنه يعد هازلا. (السابع) في تعليق الطلاق بشرط التزوج وذلك ينقسم قسمين:

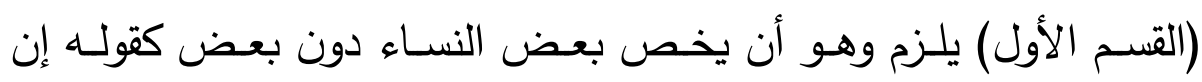

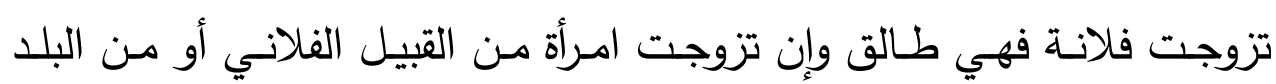

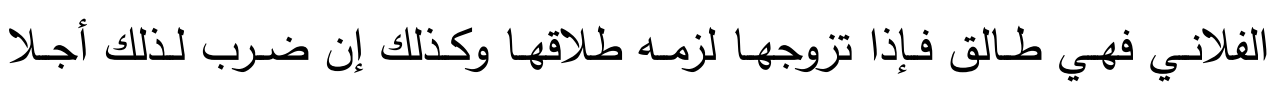
وكذلك التحريم.

(القسم الثاني) لا يلزم وهو أن يعم جميع النساء كقوله كل امرأة أتزوجها

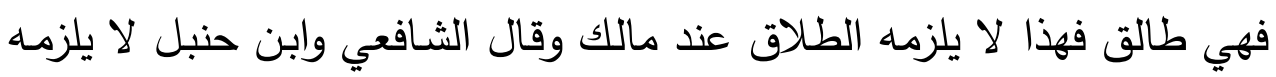

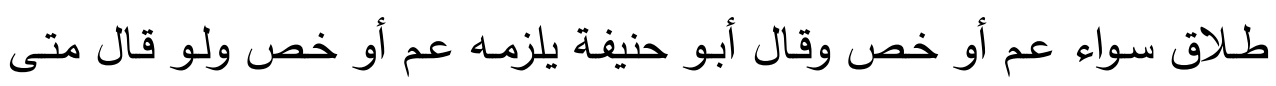
طلقتاك فأنت طالق فإذا طلقها لزمته ثلاث. (1)

') أبو القاسم، محمد بن أحمد بن محمد بن عبد الله، ابن جزي الكلبي الغرناطي (الهتوفى:

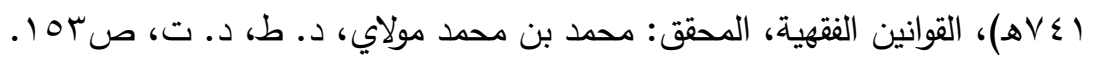


وكذا يقع الطلاق المعلق عند الشافعية، فلو قال بعد التعليق بالحلف إن ضربتاك أو إن كلمت فلاناً أو إن خرجت من الدار أو أو إن لم تخرجي أو إن لم أل

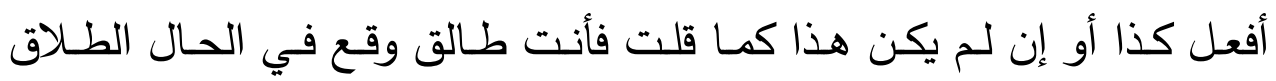

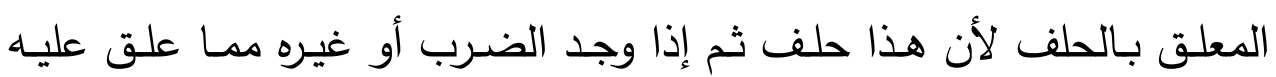

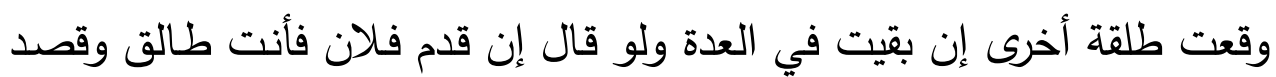

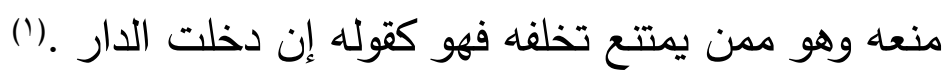
وقال الحنابلة بوقوعه، فإذا علق الطلاق بعد النكاح بوقت، طلقت بأوله؛

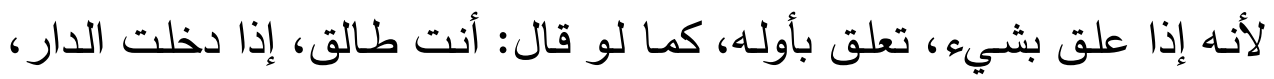

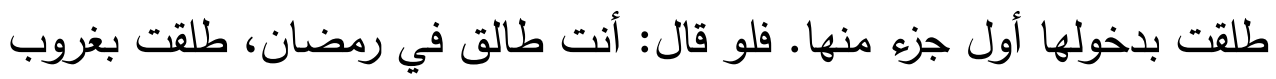
شمس شعبان. وإن قال: أنت طالق اليوم، طلقت في الحال. وإن قال: أنت طالق غداً، طلقت بطلوع فجره. فإن قال: أردت في آخر الثهر واليوم والغد، دين وهل يقبل في الحكم؟ يخرج على روايتين. وإن قال: أنت طالق في أول رمضـان، أو في غرته، طلقت في أوله، ولم يقبل قوله:

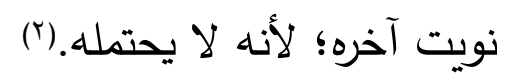

وخالف الظاهرية الجمهور في عدم وقوع الطلاق المعلق، وفي هذا يقول

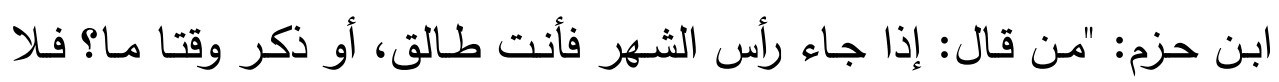

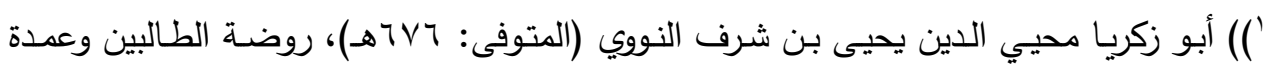

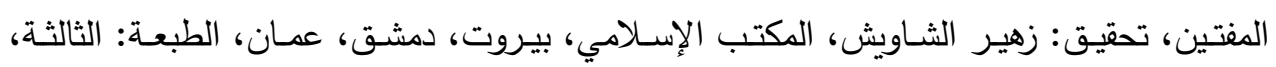

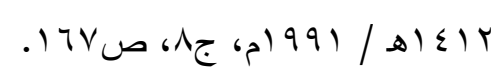

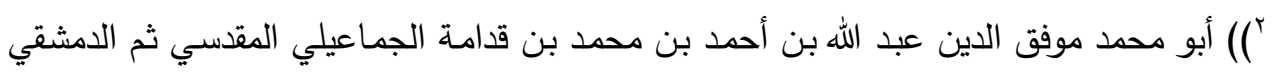

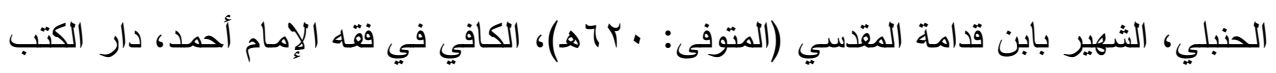

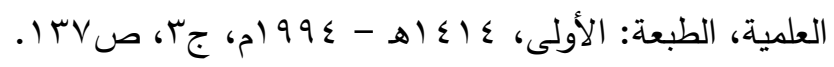


تكون طالقا بذلك، لا الآن، ولا إذا جاء رأس الشهر ... برهان ذلك: أنه لم يأت

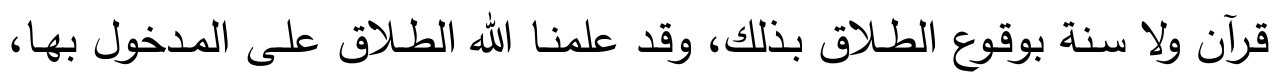

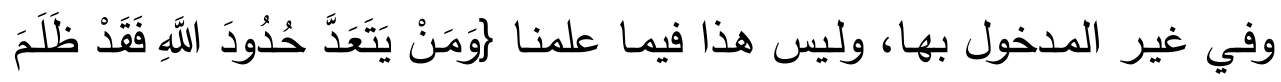

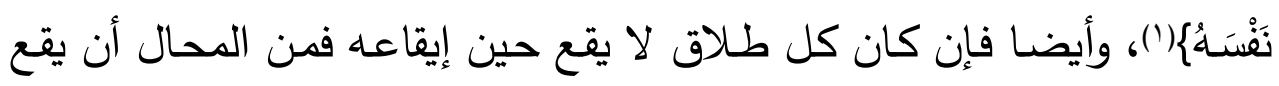

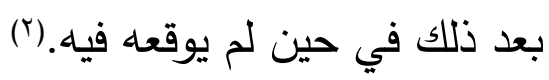

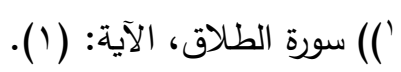

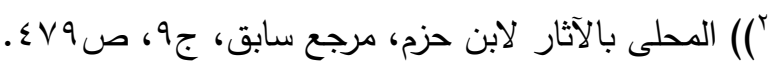




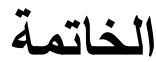

الحمد لله الذي بنعمته تتم الصسالحات، وقد انتهى هذا البحث الموسوم بـ: انفرادات ابن حزم في باب الطلاق، وقد تعرضـت فيه لترجمـة ابن حزم، ونشأة المذهب الظاهري، وأهم خصائصسه، وكيف أحياه وجدده ابن حزم، بما وضع من أصول فقهية ظاهريـة يستتد عليها في آرائه الفقهية، والتي انفرد في كثير منها عن المذاهب الأربعـة، وقد اختص هذا البحث بانفراداته في باب الطلاق.

\section{أهم نتائج البحث:}

ا ـ فقه ابن حزم الظاهري لله لون خاص امتاز بهه، وله من الآراء

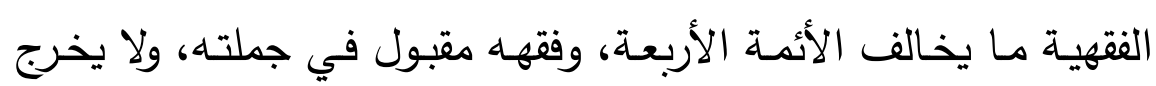
عن الكتاب والسنة غالباً.

r. المـذهب الظـاهري لـه مكانتـه في الفقـه خصوصـاً وفي الفكر الإسلامي عموماً، فالمدرسة الظاهرية ثريـة وغنية، ولا ينكر ذلك.

م. يعتبـر المـذهب الظـاهري مـن أكثر المـذاهب الفقهيـة تقيـداً

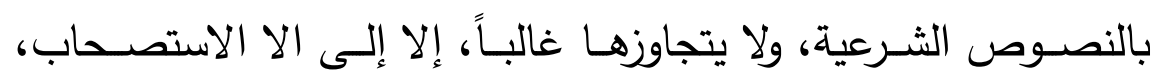
باعتباره امتداداً لها.

ـ. انفرد ابن حزم الظاهري عن جمهور الفقهاء في مسائل كثيرة، وقد ذكرت أهم هذه المسائل، والراجح فيها قول الجمهور ، ومجمل هذه المسائل على النحو التالي: وجوب الإشهاد في الطلاق والرجعة. 
إنكاره الإجماع بوقوع الطلاق في الحيض (الطلاق البدعي).

• إعلام الزوجة بالطلاق شرط لصحة الطلاق. إعلام الزوجة بالرجعة شرط لصحة الرجعة.

• طلاق المريض البائن مرض الموت كطلاق الصحيح في أثره. الطلاق لا يقع إلا بألفاظه مع وجود النية. الحلف بالطلاق والطلاق المعلق لا يقع بهما الطلاق.

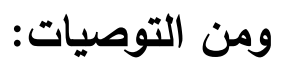

هـ ضـرورة الاهتمـام بالفقـه الظـاهري، وإعـادة الاعتبـار إليـه، فهي مدرسة فقهية فكرية تربوية عريقة.

7 ـ النظر إلي المذهب الظاهري بموضوعية وإنصاف، بـلا تحيز، أو اقتصار على بعض النقائص، أو الشذوذ في بعض المسائل. V. استيعاب آراء الظاهريـة لتقويمها، والاستفادة منها، وخلق تتوع فكري.

^. إعادة قراءة الفقـه الظاهري بطريقـة جديدة، وإبراز خصوصيات التقعيد الفقهي فيه. 


\section{| (لفهارس}

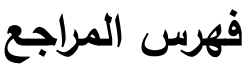

ا . علاء الدين، أبو بكر بن مسعود بن أحمد الكاساني الحنفي (المتوفى: هـAV)،

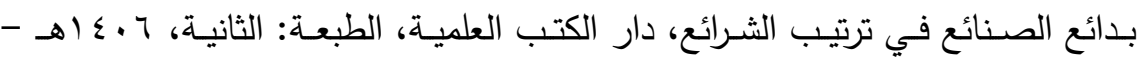
- $) 9 \wedge 7$

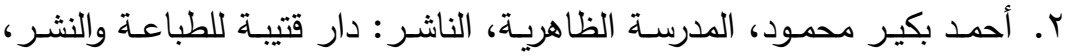

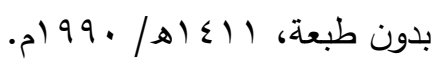

r. أبـو بكر أحمـد بـن علي بـن ثابـت بـن أحمـد بـن مهدي الخطيـب البغـدادي

(المتوفى: باج §هـ)، تـاريخ مدينـة السـلام، تحقيق: عواد معروف، الناشـر : دار الغرب

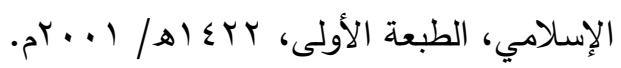

ع. أحمد بن غنيم بن سـالم النفراوي (المتوفى : بr ا اهـ)، الفواكه الدواني على

رسالة ابن أبي زيد القيرواني، المحقق : رضا فرحات، الناشر : مكتبة الثقافة الدينية، د.

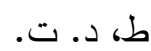

ه. أبـو العبـاس شمس الدين أحمـد بـن محمد بـن أبسي بكر بـن خلكان، وفيـات

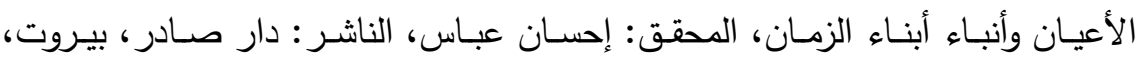

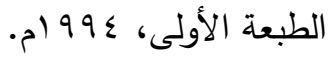

7. أبو طاهر البِّلَفي أحمد بن محمد بن أحمد بن محمد بن إبراهيم سِلَفَه البِّلَفي

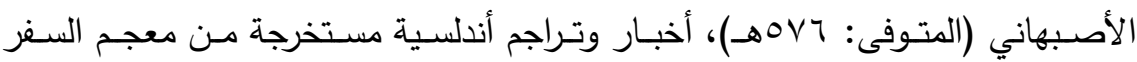
للسلفي، المحقق: إحسان عباس، الناشر : دار الثقافة، بيروت - لبنان، الطبعة الأولى، - م)

V. أبـو العبـاس أحمـد بـن محمـد الخلوتي، الثـهير بالصـاوي المـالكي (المتوفى: (اء (اهـ)، بلغة السالك لأقرب المسالك المعروف بحاشية الصـاوي على الشرح الصغير

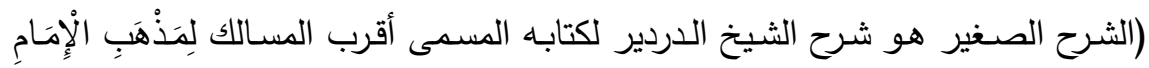
مَاللكٍ)، دار المعارف، د. ط، د. ت. 
^. خلف بن أبي القاسم محمد، الأزدي القيرواني، أبو سعيد ابن البراذعي المالكي

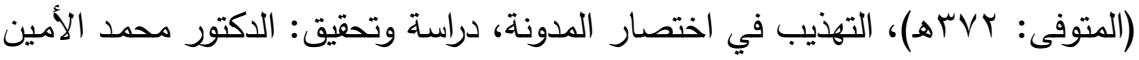
ولد محمد سالم بن الثيخ، الناشر : دار البحوث للدراسات الإسلامية وإحياء التراث، دبي،

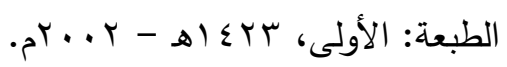

9 9. خير الدين بـن محمود بـن محمــ بـن علـي بـن فـارس، الزركلي الدمشـقي

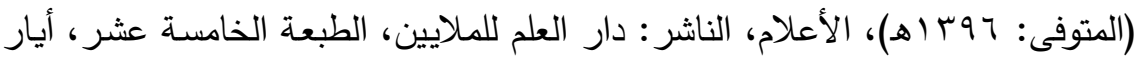

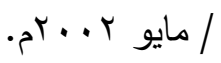

• 1 ـ عبد الرحمن بن إبراهيم بن أحمد، أبو محمد بهاء الدين المقدسي (المتوفى :

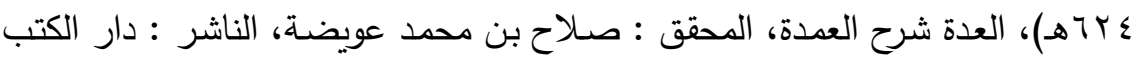

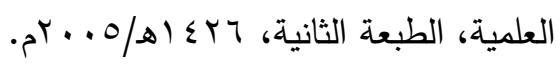

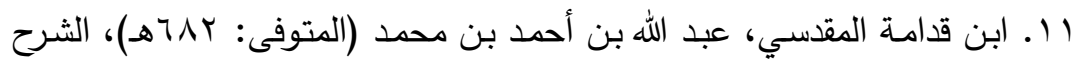

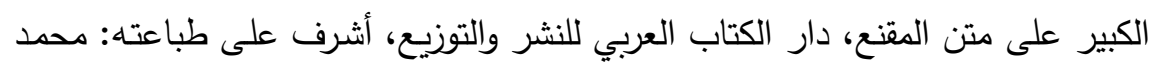

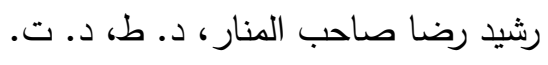

r ا ـ أبو محمد موفق الدين عبد الله بـن أحمد بـن محمد بـن قدامـة الجمـاعيلي

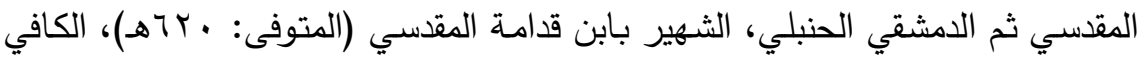
في فقه الإمام أحمد، دار الكتب العلية، الطبعة: الأولى، ـ إ أهـ - ـ99 ام. با ـ أبو محمد موفق الـدين عبد الله بـن أحمد بـن محمد، الثـهير بـابن قدامـة

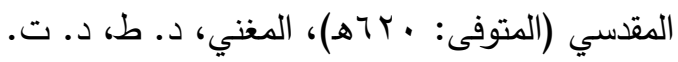

ـ ا ـ عبد الله بن محمود بن مودود الموصلي البلدحي، مجد الدين أبو الفضل : الفل

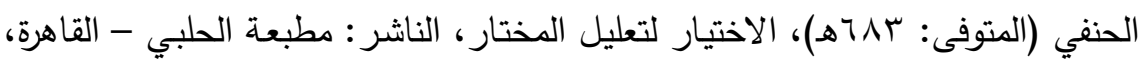

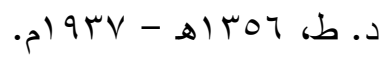

1. ـ علي بن أبي بكر بن عبد الجليل الفرغاني المرغيناني، أبو الحسن برهـان

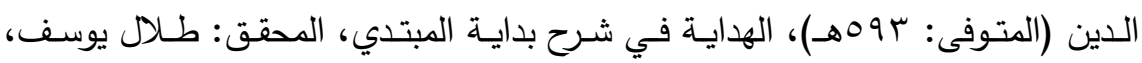

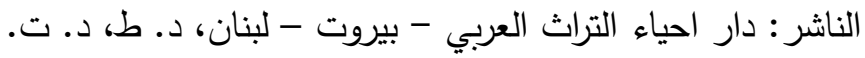


17 ـ أبو محمد علي بـن أحمد بـن سـعيد بـن حزم الأندلسـي القرطبي الظـاهري

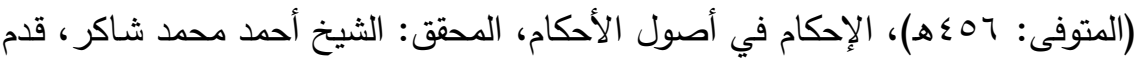

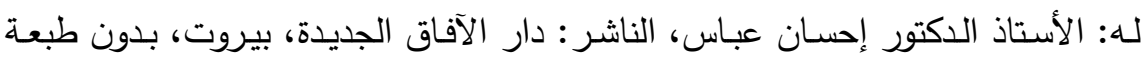

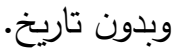

V أ أبو محمد علي بـن أحمد بـن سعيد بـن حزم الأندلسي القرطبي الظـاهري

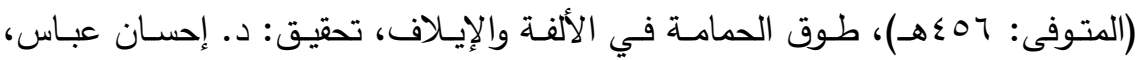
الناشر : المؤسسة العربية للدراسات والنشر، بيروت/ لبنان، الطبعة الثانية، 9 ام. 11. أبو محمد علي بـن أحمد بـن سـيد بـن حزم الأندلسي القرطبي الظـاهري

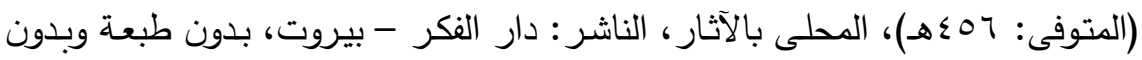

9 19 أبو محمد علي بـن أحمد بن سعيد بـن حزم الأندلسي القرطبي الظـاهري

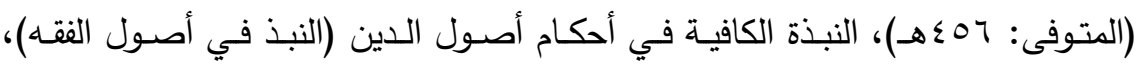
المحقق: محمد أحمد عبد العزيز ، الناشر: دار الكتب العلمية - بيروت، الطبعة الأولى.

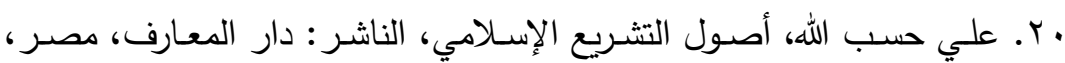

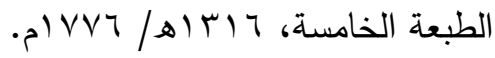

آ ا توفيق الغلبزوري، ابن حزم الأندلسي، الناشر : المنهج والمعرفة، بدون طبعة وبدون تاريخ.

r r. الإمـام محمد أبو زهرة، ابن حزم: حياته وعصره- آراؤه وفقهه، الناشر : دار الفكر العربي، القاهرة، مصر ، بدون طبعة وبدون تاريخ. r r. شمس الدين، محمد بن أحمد الخطيب الثربيني الثافعي (المتوفى: وV هـ)،

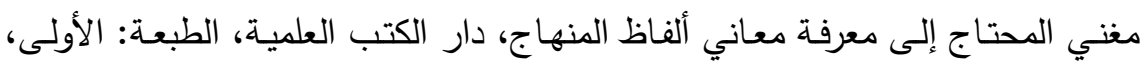
- $199 \leq-81 \leq 10$

§ r أبو القاسم، محمد بن أحمد بن محمد بن عبد الله، ابن جزي الكلبي الغرناطي

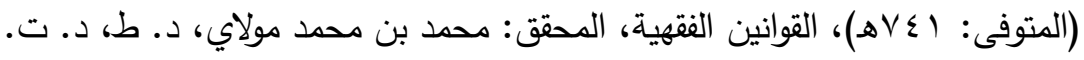




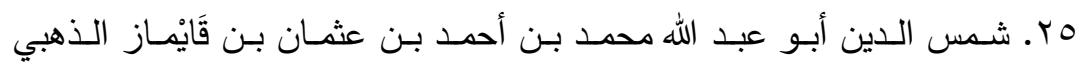

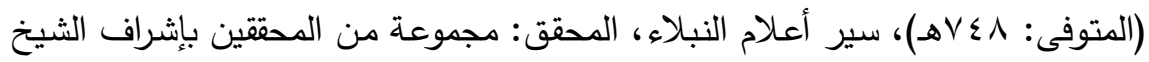

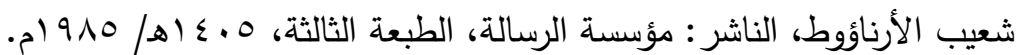
צr. أبو عبد الله محمد بن إدريس القرشي المطلبي، الثـافعي المكي، (المتوفى :

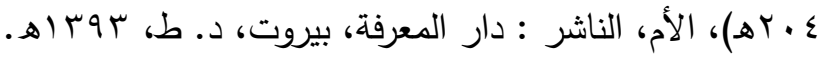

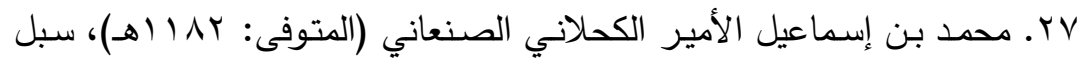

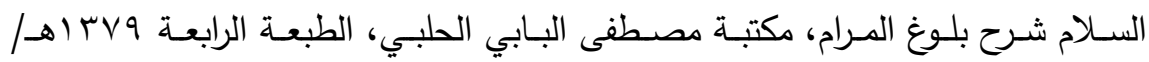
.0197.

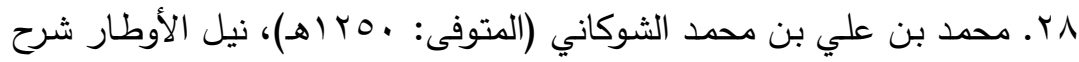

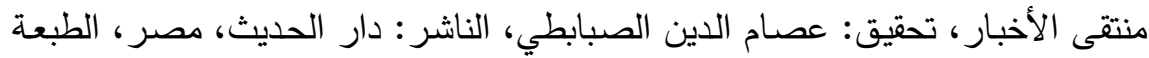

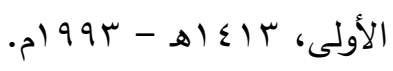

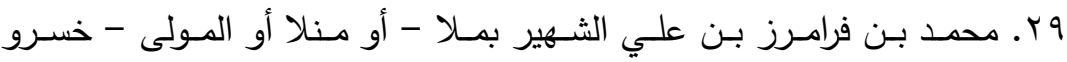

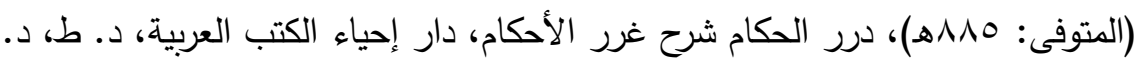

•r. أبو زكريـا محيي الدين يحيى بن شرف النووي (المتوفى: ؟YVهـ)، روضـة

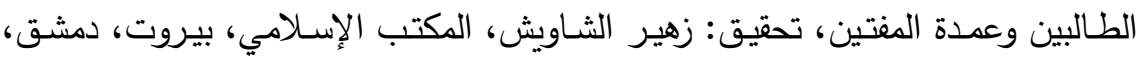
عمان، الطبعة: الثالثة، ب إ؛ اهـ / 1991 (م.

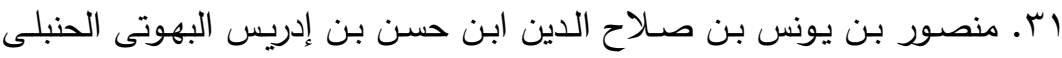

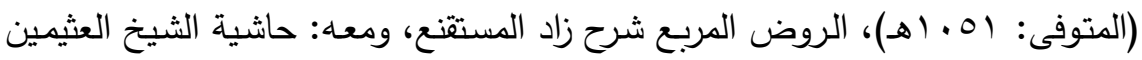

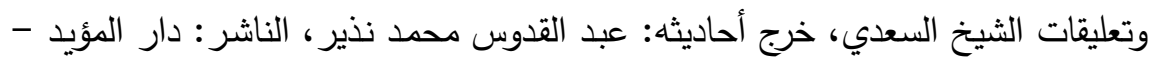

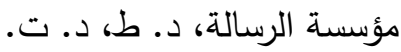

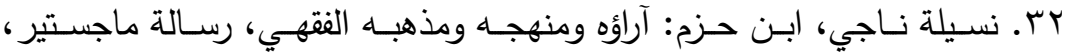

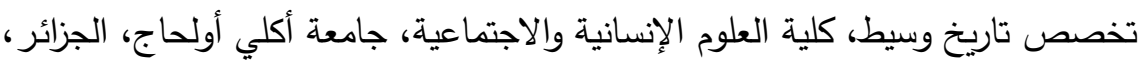

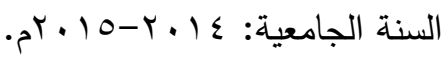


فهرس الموضوعات

\begin{tabular}{|c|c|}
\hline الصفحة & 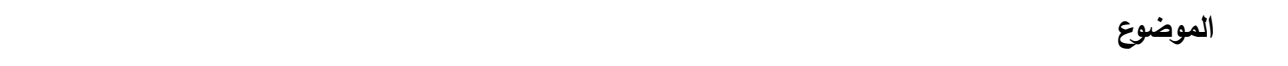 \\
\hline & المقدمة \\
\hline & التمهيد: ترجمة ابن حزم الظاهري \\
\hline & المبحث الأول: نثأة المذهب الظاهري وجهود ابن حزم في إحيائه وتجديده ومنهجه الأصولي \\
\hline & المطلب الأول: نثأة المذهب الظاهري \\
\hline & المطلب الثاني: جهود ابن حزم في إحياء الدذهب الظاهري وتجديده \\
\hline & المطلب الثالث: منهج ابن حزم الأصولي \\
\hline & المبحث الثاني: انفرادات ابن حزم في باب الطلاق \\
\hline & المطلب الأول: قوله: إن الإثهاد شرط لصحة الطلاق وصحة الرجعة \\
\hline & المطلب الثاني: إنكاره الإجماع بوقوع الطلاق في الحيض (الطلاق البدعي) \\
\hline & المطلب الثالث: قولـه: إن إعلام الزوجـة بالطلاق شرط لصحة الطلاق، وكذلك إعلام الزوجـة بالرجعة شرط \\
\hline & المطلب الرابع: قوله: إن طلاق المريض البائن مرض الموت كطلاق الصحيح في أثره \\
\hline & المطلب الذامس: قوله: إن الطلاق لا يقع إلا بألفاظه مع وجود النية \\
\hline & المطلب السادس: قوله: إن الحلف بالطلاق والطلاق المعلق لا يقع بهما الطلاق \\
\hline & الخاتمة \\
\hline & 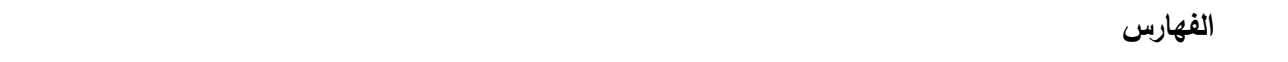 \\
\hline & 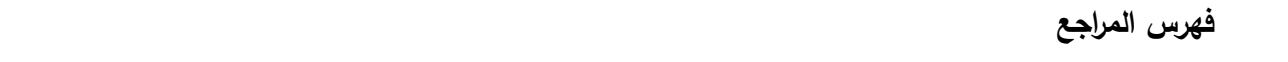 \\
\hline & فهرس الموضوعات \\
\hline
\end{tabular}

